IZA DP No. 4659

Welfare Usage in the U.S.: Does Immigrant Birthplace and Immigration Status Matter?

Ruth Uwaifo Oyelere Maharouf Oyolola

December 2009 


\title{
Welfare Usage in the U.S.: Does Immigrant Birthplace and Immigration Status Matter?
}

\author{
Ruth Uwaifo Oyelere \\ Georgia Institute of Technology \\ and IZA \\ Maharouf Oyolola \\ University of Vermont
}
Discussion Paper No. 4659
December 2009

\author{
IZA \\ P.O. Box 7240 \\ 53072 Bonn \\ Germany \\ Phone: +49-228-3894-0 \\ Fax: +49-228-3894-180 \\ E-mail: iza@iza.org
}

Any opinions expressed here are those of the author(s) and not those of IZA. Research published in this series may include views on policy, but the institute itself takes no institutional policy positions.

The Institute for the Study of Labor (IZA) in Bonn is a local and virtual international research center and a place of communication between science, politics and business. IZA is an independent nonprofit organization supported by Deutsche Post Foundation. The center is associated with the University of Bonn and offers a stimulating research environment through its international network, workshops and conferences, data service, project support, research visits and doctoral program. IZA engages in (i) original and internationally competitive research in all fields of labor economics, (ii) development of policy concepts, and (iii) dissemination of research results and concepts to the interested public.

IZA Discussion Papers often represent preliminary work and are circulated to encourage discussion. Citation of such a paper should account for its provisional character. A revised version may be available directly from the author. 
IZA Discussion Paper No. 4659

December 2009

\section{ABSTRACT \\ Welfare Usage in the U.S.: Does Immigrant Birthplace and Immigration Status Matter?*}

The study of welfare participation in the U.S. prior to the 1996 welfare reform act and even afterward has focused on comparisons between native born and immigrant households. Analyses that have gone beyond this broad classification have focused on comparisons across race or with particular focus on particular groups like Hispanic immigrants. To the best of our knowledge, there is no study yet that tests for difference in welfare usage among immigrant groups and immigrant status. We do not expect welfare usage to differ among immigrant groups if we control for the factors that should predict welfare usage. Similarly, if immigration status does not prevent welfare usage for certain immigrants, then ceteris paribus, we do not expect welfare usage to differ among immigrant based on status. We investigate these possibilities by testing three related hypothesis using probability models. Our results suggest that birth place matters and the probability of welfare usage is not the same for all groups. We also find that for some birthplace groups, citizen and non-citizens differ with respect to welfare usage. Finally, we find that post welfare reform, the probability of being on welfare in comparison to U.S. born increased for all immigrant groups and these increases differed across groups. We provide possible explanations for our unexpected results.

JEL Classification: J2, J24, J38, I21, O12, O15

Keywords: immigrants, welfare, welfare reform, immigrant status

Corresponding author:

Ruth Uwaifo Oyelere

Georgia Institute of Technology

School of Economics

221 Bobby Dodd Way

Atlanta, GA 30332-0615

USA

E-mail: ruth.uwaifo@econ.gatech.edu

\footnotetext{
* Cite only with authors' permission. Please direct any inquiries to the above address.
} 


\section{Introduction}

The issue of welfare usage among immigrants has gradually gained momentum in the last two decades in the political debates in the United States after the abuses noticed in various welfare programs- supposedly by immigrants. Although the hospitality and generosity of the United States are laudable, welfare programs are extremely costly for the American taxpayers who have asked for the overhaul of the welfare system after the revelations of many abuses within the programs. Some economists went as far as saying that some of the states have become welfare magnets for welfare seeking immigrants (Borjas, 1999). Such revelation and other evidence of welfare abuse led to the passage of the Personal Responsibility and Work Opportunity Reconciliation Act (PROWORA) in 1996, which restricts the eligibility of legal immigrants who arrived after August 1996 to the federallyfunded welfare programs for 5 years. According to Kaushal (2005), the legislation was strictly motivated by two factors: first, that the generosity of the United States is attracting low-skilled immigrants who later become a burden to the federal government. Second, immigrant dependence on means-tested programs has drastically increased, thereby raising some budgetary concerns.

Coincidentally, the post-reform period is marked with the steady increase in the inflow of immigrants into the United States from various regions. Moreover, there were various developments around the world that contributed to this surge. For instance, the 1990s saw an increase in the inflow of immigrants from war-torn African and Eastern European countries. However, after the passage of the welfare reform, the number of refugees gradually declined, according to the department of Homeland security, the 85,706 refugees in 1999 to 48218 in 2007. On the other hands, while the United States has tried to restrict the eligibility of immigrants into various federally-funded welfare programs, the number of newly naturalized immigrants has increased. According the department of Homeland Security, the number of naturalized immigrants increased from 837,418 in 1999 to $1,046,539$ in 2008 .

Although the existing literature has laid down the groundwork for future research, it has however failed to address two critical questions: First, does the birthplace of the immigrant matter with respect to their welfare participation? This problem is of great importance because when analyzing the impact of immigrants on the labor markets and welfare, previous research have lumped together the immigrants group. This paper helps solve this issue by disaggregating the dataset and examining 
the impact of immigrants birth place on the welfare participation. Second, does the immigrant status really matter with respect to their welfare usage? In other words, we want to examine whether naturalized immigrants have different welfare participation relative to noncitizen immigrants.

First, we show from a very simple model that if economic and demographic factors are the sole drivers of welfare usage, then in a probability model controlling for these variables, if we divide the sample based on place of birth, the probability of welfare usage should not differ across groups. This leads to the first hypothesis we test that birth place should not matter for welfare usage. The second hypothesis come from our expectation that the increase in restriction on welfare usage for immigrants post 1996 should lead to a decrease in the probability of welfare usage for immigrants in comparison to U.S. born. Hence we test the hypothesis that the probability of welfare usage post democracy decreased for all immigrant groups and decreased equally among these groups. The last hypothesis is based on an expectation of higher welfare usage for naturalized citizens versus noncitizen immigrant because of the restriction on the latter group post welfare reform. Hence we test the hypothesis that naturalized citizen because they lack legal restriction and hence reveal their true preference for welfare usage, have a higher probability of using welfare than noncitizens.

We test these hypothesis using simple probit models and two different measures of welfare usage: restricted and unrestricted. Controlling for economic and demographic factors that should predict welfare usage, we estimate the probability of welfare usage for the different groups in comparison to U.S. born. Our results leads to the rejection of all our hypotheses. First, although some immigrant groups share similar probability of welfare usage, birthplace seems to matter for welfare usage. Second we find that in comparison to U.S. born that the probability of using welfare increased for immigrants post welfare reform and the level of increase differed across groups. We show that this result is not driven solely by changes in immigrant population type over the last 10 years and immigrants arriving pre reform also experienced an increase in probability of welfare usage in comparison to their U.S. born counterpart. In addition, we also find that in contrast to what we expect, naturalized immigrants on average use welfare less or equal to noncitizen immigrants.

The rest of the paper is organized as follows. In section two we review the literature and highlight the welfare reform of 1996. In section three we highlight the data we will be using and present some descriptive statistics. In Section four we discuss our theoretical and economic foundations and outline 
our proposition/ hypothesis and empirical strategy. In section 5 we present our results and provide possible explanations for the results. In the last section we provide inferences and conclusions

\section{Literature Review}

The issue of immigration gained momentum in the 1990s after the passage of the Personal Responsibility and Work Opportunity Reconciliation Act (PROWORA) in 1996. Prior to the welfare reform, the literature found evidence of welfare abuse by immigrants. Borjas, (1994) noted that some "generous" states had become magnets for welfare-seeking immigrants. He also noted that immigrants with high level of productivity tend to adapt more rapidly to the host nation labor market conditions. However, the ones lacking the skills required by the host's nation employers tend to rely heavily on welfare programs to supplement their incomes. Borjas findings and the results of other immigration specialists, in addition to a public perception of U.S. born Americans that individuals were abusing the welfare system by not applying for jobs, having more children and remaining unmarried to qualify for more welfare benefits, are some of the reason that led to the passage of PROWORA.

Several studies have compared immigrant and natives welfare usage. Borjas and Trejo, (1991) found evidence that immigrant use the welfare system more intensively than natives. Borjas (1996) also finds the probability of receiving cash benefits differ for immigrant and natives though the difference is small. This result slightly contrasts with the finding of Blau (1984) who found that immigrants and native households have the same probability of participation into the welfare system. The different results might be linked to the time periods considered as there is evidence that recent immigrants tend to use welfare programs more. Also, the contrasting result again may highlight the need for specific decomposition of the immigrant native gap in welfare use by types of welfare programs. This issue was highlighted in Borjas (1996). He emphasized that although the immigrantnative difference in the probability of receiving cash benefits is really small, if other non cash programs are considered which a huge share of welfare programs is, the gap widens.

There are also several papers that show economic agents whether native or immigrants respond to differences in welfare benefits across location and time. This response to differences in welfare benefits across states has led to the classification of some states as "magnet states" for immigrants. 
Zavodny (1997) tests this magnet welfare state hypothesis noting that welfare payments are not correlated with immigration levels; rather, the presence of earlier immigrants is the primary determinant of the locational choices of new immigrants. However, the authors looked at all immigrants together and it is possible that the effect might differ within the immigrant population given the institutional and social factors that led to immigration. Her results are in contrast to Borjas (1999) who provides evidence in support of the welfare magnet thesis. He finds that immigrant welfare recipients are more heavily clustered in high-benefit states than the immigrants who do not receive welfare, or than natives. The interesting question that ties into what we will be analyzing in this paper is if the immigrants who are welfare recipient are randomly distributed among all ethnic backgrounds or if there are place of origin effects. Huffman and Kilkenny (2003) result also supports this view of labor responding to welfare programs. They investigate whether the welfare decline and labor force participation increase in the U.S. can be attributed to state welfare parameters and other opportunities. They compare welfare and labor force participation Midwestern families who are eligible for Temporary Assistance for Needy Families (TANF) to the rest of the U.S. and find evidence of differences in trends which could imply that individuals labor force participation is responsive to welfare programs both for citizens and immigrants. As mentioned above, the United States congress in response to the finding and allegations of welfare abuse of immigrants decided to grab the bull by the horns by passing the welfare reform of 1996, which restricts the eligibility of noncitizens immigrants. In response to the welfare reform, some states decided to supplement the federally funded welfare programs by providing state-funded public assistance programs to legal immigrants who have been affected by the new law. This some have concluded would have led to a more pronounced magnet state effect and might explain the differences in the Borjas (1999) in contrast to Zavodny (1997). The impact of the welfare reform on the welfare participation of legal immigrants has been investigated by several authors. Borjas (2000) noted that since welfare reform the use of welfare dropped among both natives and immigrants but with steeper decline among immigrants although immigrants still have higher participation rates. The gap in participation rates in food stamp programs he found to be attributed to differences in socioeconomic characteristics between the two groups, particularly educational attainment. He also found a strong link between use of cash benefit in the immigrant generation and the use of food stamps in the second generation. 
Borjas (2002) investigates the impact of the welfare reform on the healthcare coverage of immigrants. He finds that despite the restrictions provided by the reform, the immigrant population did not see the substantial reduction in its health care coverage. He attributed this finding to the increase in the labor supply by the immigrants after the passage of the reform, thereby raising the probability of being covered by employer-sponsored health insurance. Furthermore, Borjas (2002) examines the impact of the welfare reform on the welfare use in immigrant household. He finds that the welfare participation rate of immigrants decline relative to the natives at the national level. He attributed this drop to the decline in the welfare participation of immigrants in the state of California, which host one of the largest immigrant groups. Other research projects on the impact of the welfare reform on immigration have focused primarily on the impact of the legislation on the labor market outcomes of the latter (Lofstrom and Bean, 2002).

Although the existing literature has investigated the impact of welfare on immigrants before and after the reform, it has however failed to examine whether there is an ethnic difference in the welfare participation of immigrants. However, some recent papers on immigration in developed nations signal the need for a more decomposed analysis of immigrants. Lofstrom and Hansen(2003) provide evidence that the higher welfare utilization of immigrants in comparison to natives is not solely an American phenomena, using a large panel data of Sweden. More importantly, they find that differences among immigrants exist. They find that refugee immigrant display substantially higher public assistance participation rates upon arrival in Sweden compared to non-refugee immigrants, but they assimilate out-of welfare at a faster rate than non-refugee immigrants. Ekhaugen (2005) also finds differences among immigrants to Norway with respect to welfare usage overtime. She finds that non-western immigrants to Norway rely heavily on welfare transfers and this continues for several years after immigration. Interesting and unexpectedly, she finds some evidence of assimilating out of welfare for refugee while other non-western immigrants assimilate rapidly into welfare. The need for more specific decomposition of welfare program usage among immigrants and native born can also be inferred from some of the results of Borjas (1996). He highlighted ethnic networks as a potential channel for transmission of the knowledge of the available welfare programs between newly arrived and earlier immigrants. Hence, if economic and education status of early migrants differs among immigrant groups, then even if new migrants from the same immigrant group are 
poor and more likely to use welfare they will have less information than another poor immigrant groups whose early migrants used the welfare programs intensively. These differences in information can lead to differences in welfare usage among different immigrant groups. For example if early African migrants to the US were highly educated and less likely to use welfare then there might be a lower probability that the new African immigrants might use the welfare programs even if they came in as refugees or via the visa lottery . The exact opposite might also be true if early immigrant from another country or ethnicity tend to be poor and uneducated and needed to use the welfare programs much more. Finally, there is not as much in the U.S. on exit from welfare usage or assimilation out of welfare programs. Lofstrom and Hansen(2006) is one paper that focuses on this question in the case of Sweden. They try to explain the role of entry and exit rates on immigrant-native differences in welfare participation. However Ekhaugen (2005) and Lofstrom and Hansen(2003) results might suggest that there are group differences among immigrants with respect to exit out of welfare programs. Both papers find that refugees exit faster from welfare programs than other immigrant group. Our paper attempts to fill the void in analysis of the U.S. experience by examining if there are ethnic differences in welfare participation and if response rates differed across different groups post the 1996 welfare reform. In addition, we examine the role of immigration status on welfare usage.

\subsection{Overview of the 1996 Welfare Reform}

In light of the abuses noticed in the different welfare programs, congress passed the Personal Responsibility and Work Opportunity reconciliation Act (PRWORA) in August 1996. The PRWORA excludes legal noncitizens that arrived after August 1996 from various federally-funded welfare programs. Thus immigrants who arrived after the aforementioned period were not eligible for meanstested programs such as foodstamps, Supplemental Security Income (SSI), for at least 5 years. Strong opposition from immigrant advocates led the federal government to restore food stamps and Supplemental Security Income (SSI) for the children, disabled and elderly (Kaushal, 2005). It is important to mention that in response to the restrictions of the eligibility of immigrants to the welfare programs, the federal government gave the different states the options of extending benefits to legal noncitizens that have been affected by the new law and some states did. Some states have used state-funds to either supplement or restore safety-net programs for their most vulnerable 
immigrants. Thus states such as California, New York and Texas that host large immigrant populations have extended eligibility to newly-arrived immigrant groups. According to Kaushal (2005), "10 states have created food stamps programs, 15 have substitute Medicaid, 3 have substitute SSI, and 19 have provided funds for the welfare needs of newly arrived immigrants. Of the six traditional immigrant states where three-fourths of all immigrants live, only California provides newly arrived immigrant families access to all four programs. In Illinois and New York, newly arrived immigrants get Medicaid but no other benefits. In Texas, Florida, and New Jersey, newly arrived immigrants get none of these benefits." Moreover, immigrants themselves have also increased their labor force to mitigate the effect of the reform on the healthcare (Borjas, 2003).

Prior to the 1996 reform, with the exception of refugees, all immigrants were entitled to AFDC and SSI three years after their arrival (Hao and Kawano,2001). However, due to the numerous abused of the various programs noticed, congress passed the law despite the outcry from the various immigrants advocates. The welfare reform placed explicit restrictions on the eligibility of noncitizens to receive the temporary Assistance for Needy families (TANF)1, food stamps, Medicaid, SSI and other health and social service programs (Lofstrom and Bean, 2002). This law particularly targeted legal immigrants who entered the country after August 22, 1996. The need to restrict the access of legal immigrants to the welfare system stems from the debates that immigrants were using extensively welfare programs and that the United States was attracting low-skilled immigrants who later on become a liability to the host country. Another reason for the passage of the law is the general perception that some immigrants make their immigration to the United States on the basis of the generosity of the welfare programs, which is known in the literature as the "welfare magnet" hypothesis. According to Kaushal (2005), this legislation was strictly motivated by two factors: first, there was a general perception that immigrants were abusing the welfare system. Second, there was fear that the US welfare system was attracting low-skilled immigrants who are likely to become a liability to the system.

\section{Data}

The data used in this paper come from the Current Population Survey (CPS). The CPS is a monthly survey sponsored by the Census Bureau and the Bureau of Labor Statistics (BLS) that provides 
information about individual persons and households. In this study we specifically make use of the data from the 1994-2008 CPS March supplements. The questions center on demographic characteristics, income and other economic variables as well as labor market activities. It also includes other annual supplementary information like health insurance. We derive multi-stage stratified samples of the CPS from IPUMS. We select the period of 1994-2008 for our analysis because the question on immigrants birth place continent was only introduced in 1994 and fully defined from 1995. The break down of birth place continent was limited in the 1994, for example, we cannot differentiate immigrants from Africa from immigrants from most parts of Asia. Given our main focus is in differences in birth place continent in welfare usage, this means we only have one years before the welfare reform in our dataset and 12 years post the reform. Also controlling for health is important in predicting welfare usage and this variable is only available from 1996 in the CPS. Hence we will focus on the 1996-2008 data for most of our estimations to adequately control for this factor. For the hypothesis for which we are interested in comparing pre and post reform welfare usage, we will eliminate this control and compare pre and post reform estimates without controlling for health status.

One of the advantages of using the CPS via IPUMS is that it makes cross-time comparisons using the March CPS data more feasible as variables in IPUMS-CPS are coded identically or "harmonized" for 1962 to 2008. The CPS data can be used to create a two-year panel by matching the Outgoing Rotation Group (ORGs) between consecutive survey years. The ORG component is made possible because the CPS uses a 4-8-4 sampling scheme. This means that each household is in the survey for four consecutive months, out for the next eight, and then returns for the following four months. We however do not make use of this property because of problems faced with trying to match observations over the two consecutive years in IPUMS.

\subsection{Descriptive Statistics}

As stated above, the objective of this study is to examine whether the birthplace and educational background of immigrants matter with respect to the welfare usage. Table 1 provides the summary statistics of various welfare forms across natives and immigrant groups. Specifically, we present the welfare usage of food-stamp, heat subsidy, public housing, welfare income and any form of welfare. With respect to food-stamp, our table shows that other North American immigrants have 
Table 1: Welfare Usage by Birth Place

\begin{tabular}{|c|c|c|c|c|c|c|c|c|c|c|}
\hline & & Africa & $\overline{~ C . A . C ~}$ & Asia & Europe & $\begin{array}{c}\text { South } \\
\text { America }\end{array}$ & Oceania & $\begin{array}{c}\text { Natives } \\
\text { Born } \\
\end{array}$ & Other & $\begin{array}{c}\text { North } \\
\text { America }\end{array}$ \\
\hline & & (1) & (2) & (3) & (4) & $(5)$ & (6) & (7) & (8) & (9) \\
\hline \multirow{3}{*}{$\begin{array}{l}\text { Food } \\
\text { stamp }\end{array}$} & Mean & 1.072 & 1.1 & 1.048 & 1.045 & 1.046 & 1.055 & 1.084 & 1.091 & 1.27 \\
\hline & Stand. Dev. & 0.25 & 0.3 & 0.21 & 0.2 & 1.011 & 0.22 & 0.27 & 0.28 & 0.44 \\
\hline & $\mathrm{N}$ & 7868 & 146666 & 68586 & 42441 & 20624 & 1599 & 2245738 & 9424 & 3827 \\
\hline & Mean & 1.017 & 1.018 & 1.012 & 1.018 & 0.53 & 1.009 & 1.03 & 1.029 & 1.09 \\
\hline \multirow[t]{2}{*}{ Subsidy } & Stand. Dev. & 0.12 & 0.13 & 0.11 & 0.13 & 0.54 & 0.096 & 0.17 & 0.16 & 0.29 \\
\hline & $\mathrm{N}$ & 7868 & 146666 & 68586 & 42441 & 20624 & 1599 & 2245738 & 9424 & 3827 \\
\hline Public & Mean & 0.56 & 0.59 & 0.42 & 0.32 & 0.53 & 0.5 & 0.29 & 0.53 & 0.81 \\
\hline \multirow[t]{2}{*}{ Housing } & Stand. Dev. & 0.58 & 0.55 & 0.53 & 0.5 & 0.54 & 0.57 & 0.51 & 0.57 & 0.72 \\
\hline & $\mathrm{N}$ & 7868 & 146666 & 68586 & 42441 & 20624 & 1599 & 2245738 & 9424 & 3827 \\
\hline Welfare & Mean & 0.016 & 0.021 & 0.01 & 0.009 & 0.009 & 0.008 & 0.013 & 0.023 & 0.047 \\
\hline \multirow[t]{2}{*}{ Income } & Stand. Dev. & 0.12 & 0.14 & 0.1 & 0.09 & 0.094 & 0.091 & 0.11 & 0.15 & 0.21 \\
\hline & $\mathrm{N}$ & 7137 & 134609 & 63590 & 38856 & 19046 & 1428 & 1649500 & 8570 & 23120 \\
\hline \multirow{3}{*}{$\begin{array}{l}\text { Any form } \\
\text { of welfare }\end{array}$} & Mean & 0.067 & 0.11 & 0.061 & 0.051 & 0.055 & 0.051 & 0.056 & 0.09 & 0.16 \\
\hline & Stand. Dev. & 0.25 & 0.31 & 0.24 & 0.22 & 0.22 & 0.22 & 0.23 & 0.28 & 0.36 \\
\hline & $\mathrm{N}$ & 7868 & 146666 & 68586 & 42441 & 20624 & 1599 & 2245738 & 9424 & 25578 \\
\hline
\end{tabular}

Note: Standard Dev. -Standard Deviation

C.A.C- Central America and the Caribbeans

the highest food-stamp usage, followed by the Central American immigrants. Other North American immigrants consist of immigrants from North American countries like Canada and Bermuda as well as immigrants from U.S. protectorates like Puerto Rico. Later on in the empirical section of the paper, we break down this group into two to highlight that the high welfare usage is peculiar to solely those from the U.S. protectorate. Another salient element of the table is the fact that the North American immigrants have on average the highest welfare usage in public housing. Overall, table 1 indicates that the Other North American immigrants have on average the highest welfare usage in food-stamp, public housing, welfare income and any form of welfare. This immigrant group is followed by the Central American immigrants. Besides the welfare usage across immigrant groups, we also present in Table 2 the welfare usage of immigrants by their educational attainment. Educational attainment ranges from less than 8th grade to doctorate and professionals. With respect to the educational attainment, the table shows that the North American immigrants have the highest welfare usage from less than 8th grade up to the associate degree. This group is followed by African 
immigrants with a high school diploma or less. However, we notice that for levels of education of a bachelor degree or higher, immigrants from Central America have the highest welfare usage followed my immigrants from Europe. The surprising element of the table is the differences across immigrant groups in the intensity of the welfare usage for each level of education. Interestingly, the results in this table provide some support for the public perception that immigrants from the third world countries have an intensive usage of the welfare programs especially at the lower levels of education. As mentioned above, some of the abuses noticed within the system led to the passage of the PRWORA in 1996. Table 3 summarizes welfare usage across immigration status. We divide immigrants into those who are naturalized and does who are not. We call those who are not naturalized citizens "non citizen immigrants". This category consist of permanent residents, those on visas and those who are illegal immigrants. Interestingly, Table 3 seems to suggest that nonnaturalized immigrants use welfare programs more intensively than the naturalized immigrants for all immigrant groups apart from other North Americans (Canada and Bermuda). This result is surprising giving the fact that many non-naturalized immigrants are not eligible for any welfare programs because they are on visas or illegal. In addition, post 1996 even permanent residents experienced added restrictions in access to welfare. A plausible explanation of this fact is that the vast majority of the naturalized immigrants had already adjusted to the cultural and language barriers and some other hurdles at the beginning of their "journey" on the host country's soil. This explanation validates the assimilation theory, which argues that immigrants tend to diminish the language and cultural barriers over time by also improving their occupational skills (Kazemipur and Halli, 2001). Another plausible reason may be the stigma attached to being part of the welfare within the community might deter naturalized immigrants from taking part in welfare programs. Unlike newly arrived immigrants who have to face more obstacles before adjusting to the host nation's lifestyle, the naturalized are well-established and may attach more importance to fitting in as Americans. 
Table 2: Welfare Usage by Birth Place and Education Level

\begin{tabular}{|c|c|c|c|c|c|c|c|c|c|}
\hline \multirow[t]{2}{*}{$\begin{array}{c}\text { Education } \\
\text { Level }\end{array}$} & & Africa & C.A.C & Asia & $\overline{\text { Europe }}$ & $\begin{array}{c}\text { South } \\
\text { America }\end{array}$ & Oceania & $\begin{array}{c}\text { Natives } \\
\text { Born } \\
\end{array}$ & $\begin{array}{c}\text { Other North } \\
\text { America }\end{array}$ \\
\hline & & (1) & $(2)$ & (3) & (4) & (5) & (6) & (7) & (8) \\
\hline \multirow{3}{*}{$<8$ th grade } & Mean & 0.28 & 0.16 & 0.24 & 0.097 & 0.14 & 0.17 & 0.2 & 0.36 \\
\hline & Stand. Dev. & 0.45 & 0.36 & 0.42 & 0.29 & 0.35 & 0.38 & 0.4 & 0.48 \\
\hline & $\mathrm{N}$ & 470 & 47363 & 5541 & 3944 & 1858 & 63 & 82467 & 3827 \\
\hline \multirow[t]{2}{*}{$9-12$ th grade } & Mean & 0.17 & 0.13 & 0.13 & 0.089 & 0.095 & 0.1 & 0.15 & 0.3 \\
\hline & Stand. Dev. & 0.37 & 0.34 & 0.34 & 0.28 & 0.29 & 0.3 & 0.36 & 0.46 \\
\hline & $\mathrm{N}$ & 608 & 28900 & 5357 & 3426 & 2443 & 162 & 245399 & 4202 \\
\hline \multirow{3}{*}{ school } & Mean & 0.073 & 0.088 & 0.068 & 0.058 & 0.053 & 0.067 & 0.074 & 0.13 \\
\hline & Stand. Dev. & 0.26 & 0.28 & 0.25 & 0.23 & 0.22 & 0.25 & 0.26 & 0.34 \\
\hline & $\mathrm{N}$ & 2785 & 44010 & 21821 & 16678 & 8942 & 722 & 827877 & 9501 \\
\hline \multirow[t]{3}{*}{ Associate } & Mean & 0.038 & 0.072 & 0.042 & 0.043 & 0.035 & 0.033 & 0.042 & 0.073 \\
\hline & Stand. Dev. & 0.19 & 0.25 & 0.2 & 0.2 & 0.18 & 0.18 & 0.2 & 0.26 \\
\hline & $\mathrm{N}$ & 519 & 4396 & 3809 & 2835 & 1183 & 120 & 126929 & 1444 \\
\hline \multirow[t]{3}{*}{ Bachelor } & Mean & 0.029 & 0.054 & 0.022 & 0.036 & 0.027 & 0.004 & 0.014 & 0.027 \\
\hline & Stand. Dev. & 0.16 & 0.22 & 0.14 & 0.18 & 0.16 & 0.065 & 0.11 & 0.16 \\
\hline & $\mathrm{N}$ & 1742 & 7235 & 16946 & 7001 & 3126 & 233 & 248420 & 2717 \\
\hline \multirow[t]{3}{*}{ Masters } & Mean & 0.016 & 0.033 & 0.01 & 0.028 & 0.016 & 0 & 0.008 & 0.02 \\
\hline & Stand. Dev. & 0.12 & 0.18 & 0.1 & 0.16 & 0.12 & 0 & 0.09 & 0.14 \\
\hline & $\mathrm{N}$ & 596 & 1664 & 6482 & 3209 & 922 & 83 & 84296 & 859 \\
\hline \multirow{3}{*}{$\begin{array}{c}\text { Doctoral \& } \\
\text { professionals }\end{array}$} & Mean & 0.004 & 0.033 & 0.009 & 0.029 & 0.013 & 0 & 0.006 & 0.005 \\
\hline & Stand. Dev. & 0.069 & 0.18 & 0.09 & 0.16 & 0.11 & 0 & 0.08 & 0.07 \\
\hline & $\mathrm{N}$ & 417 & 1041 & 3634 & 1763 & 572 & 45 & 34112 & 570 \\
\hline
\end{tabular}

Note: Standard Dev. -Standard Deviation

C.A.C- Central America and the Caribbeans

\section{Theoretical/Economic Foundations of Hypotheses}

We assume that the probability a person i in country $\mathrm{T}$ uses welfare is a function of a set of variables $\mathrm{X}$.

$$
\operatorname{Prob}(W=1)=F(X)
$$

$\mathrm{X}$ is a matrix of all the expected economic and noneconomic variables or factors impacting the probability of welfare usage. Variables included in X are sex, age, marital status, employment status, wages, location (state), immigrants cohort, year of immigration and health status. Government assistance is usually associated with low levels of living and poverty. We capture the effect of poverty by including the control variables wages and number of children, which both influence if an 
individual will be considered poor. If $\mathrm{Y}=1$, an individual uses welfare, whereas $\mathrm{Y}=0$ indicates that an individual does not use any form of government welfare or assistance.

If country $\mathrm{T}$ consist of three types of people. Those born in $\mathrm{T}$ (BT), those who immigrate to $\mathrm{T}$ and are now naturalized citizens (NT) and all other immigrants to T (IT). We assume that being an immigrant does not necessitate welfare usage. Hence $\operatorname{Prob}(\mathrm{W}=1)$ should be identical for comparable immigrants and U.S. born citizens. Hence, ceteris paribus, $\operatorname{Prob}(W=1)_{B T}=\operatorname{Prob}(W=1)_{N T}=$ $\operatorname{Prob}(W=1)_{I T}$. Meaning that if $X_{B T}=X_{N T}=X_{I T}$ for a group of individuals then such a group of individuals no matter their citizen status will have similar probability of using welfare in country T. If individuals in group NT and IT have home countries ranging from $\mathrm{i}=1 \ldots \ldots . \mathrm{n}$. Then as long as $X_{i, N T}=X_{2, N T}=\ldots \ldots \ldots \ldots X_{n, N T}$ for a subset of individuals or $X_{i, I T}=X_{2, I T}=\ldots \ldots \ldots X_{n, i T}$, the probability of being on welfare should not differ. Meaning $\operatorname{Prob}(W=1)_{i, N T}=\operatorname{Prob}(W=1)_{2, N T}=$ $\operatorname{Prob}(W=1)_{3, N T}=\operatorname{Prob}(W=1)_{1, I T}=\operatorname{Prob}(W=1)_{2, I T} \ldots \ldots \ldots \operatorname{Prob}(W=1)_{n, I T}=\operatorname{Prob}(W=$ $1)_{n, N T}$.

We can apply the above frameworks for country $\mathrm{T}$ to the U.S. If being an immigrant is not casually linked with welfare usage and economic and demographic factors can fully explain welfare usage, then in an econometric analysis, if we control for the X's (demographic and economic factors), the probability of using welfare should be the same for U.S. born citizens and immigrants. Similarly, there should be no statistical difference in the probability of using welfare based on place of birth or origin if we control for the X's that predict welfare usage. This leads to the first hypothesis we test. This hypothesis has two parts Hypothesis 1a: After controlling for factors that affecting welfare usage, birthplace does not matter for welfare usage in the U.S. Hence, immigrants and U.S. born have similar welfare usage. Hypothesis 1b: After controlling for factors that affecting welfare usage, welfare usage is identical for all immigrant groups to the U.S.

Returning to our simple model framework of country $\mathrm{T}$ again, if post period $\mathrm{t}$, restrictions are placed on immigrants IT such that they are unable to use welfare until they become NT, then even if $X_{B T}=X_{N T}=X_{I T}$, for period $t+1, \operatorname{Prob}(W=1)_{B T}=\operatorname{Prob}(W=1)_{N T}>\operatorname{Prob}(W=1)_{I T}$. Hence in period $t+1$, the $\operatorname{Prob}(W=1)_{I T}<\operatorname{Prob}(W=1)_{I T}$ in period $t-1$. If we assume $\Delta=$ $\operatorname{Prob}(W=1)_{I T}^{t+1}-\operatorname{Prob}(W=1)_{I T}^{t-1}$ and if we assume that $X_{i, I T}=X_{2, I T}=\ldots \ldots \ldots X_{n, i T}$, then $\Delta_{i, I T}=\Delta_{2, I T}=\Delta_{3, I T} \ldots . . \Delta_{n, I T}$. Meaning that if the X's are identical across all i's the change in 
probability of welfare usage for group IT should decrease similarly no matter the birth continent post the restriction in period t. Also, given that naturalized citizens are a select group and post reform the issue of selectivity becomes more important. If individual i was using welfare before reform and met the criteria for citizenship but never pursued it because of the fixed cost of application or other personal reasons, post reform, individual L is likely going to apply for citizenship as long as the total cost of applying for citizenship is less than the benefit gained from welfare support. Hence post reform the probability of using welfare for naturalized immigrants should rise while the probability of using welfare for noncitizens should decrease. As above, we expect this change in behavior to be consistent across immigrant group. Hence for comparable naturalized individuals, the $\operatorname{Prob}(\mathrm{W}=1)$ should be the same, regardless of birthplace. Similarly, for comparable noncitizens, the $\operatorname{Prob}(\mathrm{W}=1)$ should be the same, regardless of birthplace. We can apply these simple expectation to the U.S. and this leads to our second and third hypothesis. Hypothesis 2: Given welfare reform led to an increase in restriction on welfare usage by immigrants who not citizens, then post reform, the probability of using welfare should decrease for all immigrant groups in comparison to U.S born, ceteris paribus. However among immigrants, welfare usage should decrease equally for comparable individuals regardless of birth place continent. Our third hypothesis, which consists of three parts is also based on the principles and expectations laid out above. Hypothesis 3a: Ceteris paribus, Naturalized Americans regardless of their birthplace have a higher probability of welfare usage than comparable Noncitizen immigrants. Hypothesis 3b:Ceteris paribus, the use of welfare is similar for comparable noncitizens regardless of their birthplace. Hypothesis 3c: Ceteris paribus, the probability of welfare usage is similar for comparable naturalized citizens regardless of their birthplace.

Next, we further investigate what could lead to the rejection of the three above hypothesis. For example, if $\operatorname{Prob}(W=1)_{1, N T} \neq \operatorname{Prob}(W=1)_{3, N T} \neq \operatorname{Prob}(W=1)_{2, I T} \cdots \neq \operatorname{Prob}(W=1)_{n, I T}$ after controlling for the X's in a probit model estimation, then it means that citizenship status and or birth place matters in predicting welfare usage. Similarly, such a finding could imply citizenship status or birth place are proxing for other variables not included in $\mathrm{X}$ that we do not traditionally expect to affect welfare usage. It is not impossible that citizenship status could matter in the U.S. because of the restrictions on welfare usage for noncitizens. These restrictions increased significantly post 1996 
when the massive welfare reform was implemented as described in section 2.1 above. Hence even if individual i's X is identical to individual k's X, who is not a citizen, welfare usage would differ because of the ineligibility of $\mathbf{k}$. Hence the true preference of $\mathbf{k}$ is not revealed in the data and and may create an artificial difference in the probability of welfare usage. Given the true preference is revealed for all who are eligible for welfare, then we should not expect U.S. born citizens, U.S. citizens from the protectorates and U.S. naturalized citizens who share similar X's to differ in welfare usage. If they still do, then it implies that type of citizen matters. Similarly if U.S. naturalized citizens who share similar X's differ in welfare usage based on continent of birth, then it means that birth place matters. Birth place or citizenship type could matter if it is proxing for culture, information, institutional experience or values of a group. These are variables that we will not typically include in our X matrix and will not be not include in our regression analysis. We do not include such variables because we do not traditionally expect values, past institutional experiences, access to information or culture to play a role in welfare usage. However if our birthplace affects our culture, access to information and values and a groups culture and value affect their preferences for assistance from the government, then even if $X_{1}=X_{2} \ldots \ldots=X_{Z}$ is the same for a subset of individuals from birthplaces i....n, prob(W=1) will still differ across birth places for this subset of individuals, as long as culture or values differ based on birth place. Similarly, if the institutions immigrants are exposed to before they immigrate affect the way they view the government and the role of the government with respect to getting assistance, then welfare usage may differ across immigrant groups from different parts of the world again even though they share similar X's. Also, if people select to becoming naturalized citizens as a mark of their allegiance to a country and this come with a preference of giving back to the country versus taking, then naturalized citizens might actually have lower probability of using welfare than noncitizens. This is similar to the thesis that becoming a naturalized citizen may move individuals into a class or group in the U.S. where perception of welfare usage is negative. In this scenario, naturalized immigrants in a bid to fit into the group might stop using welfare. In addition, if immigrants from different birth places, view becoming a citizen in the U.S. differently and this view or perception affects welfare usage, then among naturalized citizens, the probability of using welfare may differ across immigrant groups despite similar X's for the individuals. 


\section{Empirical Strategy}

Recall the focus of our analysis is to test three hypotheses that are expectations from our simple framework highlighted above. Again we recap these hypothesis:

- Hypothesis 1a: Birthplace does not matter for welfare usage in the U.S. Hence, immigrants and U.S. born have similar welfare usage. Hypothesis 1b:Welfare usage is identical among immigrant groups to the U.S.

- Hypothesis 2: Given welfare reform led to an increase in restriction on welfare usage by immigrants who not citizens, then post reform the probability of using welfare should decrease for all immigrant groups in comparison to U.S. born, ceteris paribus. However among immigrants, welfare usage should decrease equally for comparable individuals regardless of birth place continent.

- Hypothesis 3a Ceteris paribus, Naturalized Americans regardless of their birthplace have a higher probability of welfare usage than comparable Noncitizen immigrants. Hypothesis 3bCeteris paribus, the use of welfare is similar for comparable noncitizens regardless of their birthplaceHypothesis 3c: Ceteris paribus, the probability of welfare usage is similar for naturalized citizens regardless of their birthplace

To test these hypotheses we rewrite equation 1 assuming a probit model as in equation 2 .

$$
\operatorname{Prob}(Y=1)=\Phi\left(\alpha_{0}+\alpha_{1} \Omega+\alpha_{2} Z+\alpha_{3} W+\sum_{i} \psi_{i} R_{i}\right)
$$

where $\mathrm{Z}$ is a matrix of all the possible factors impacting the probability of welfare usage. The dependent variable $\mathrm{Y}$ is a binary indicator which takes on a value of 1 if an individual is on some form of welfare and a value of 0 if the individual is not. $\Phi($.$) in equation (2) indicates the standard normal$ distribution. Variables included in the $\Omega$ matrix are predictors of welfare usage like education, number of children in the family, size of the family, marital status, employment status and for immigrants- years in the U.S. $Z$ is a matrix of dummy variables including year and region dummies. $\mathrm{W}$ represents wage which is an important predictor of welfare usage. $\mathrm{R}$ is the matrix of the variables we are primarily interested in. The $\mathrm{R}$ matrix can have different dummy variables depending on 
the model we are testing. In our main model, our $\mathrm{R}$ matrix consists of dummy variables based on place of birth that divides the sample as follows: born in the U.S., born in U.S. protectorates, born in other North America (not U.S.), born in Central American and the Caribbeans, born in South America, born in Europe, born in Asia, born in Africa, born in Oceania and finally the group others. The group others are those who did not choose or indicate a place of birth. Variable $\mathrm{Y}$ is measured in two ways the restricted or standard welfare usage and the nonrestricted extended welfare usage. For the restricted welfare usage, an individual gets $\mathrm{Y}=1$ if the individual gets one or more of these three welfare programs: food stamps, supplemental security income (SSI) or receiving any income during the previous calendar year from various public assistance programs commonly referred to as "welfare". For the unrestricted measure of welfare or government assistance, an individual gets $\mathrm{Y}=1$ if any of the above three are received or if the individual gets government subsidized rent or government subsidized heating.

We choose a probit modeling strategy as against a linear probability model though the linear probability specification of the binary choice model also provides ease of interpretation. This is because in the linear model, unless restrictions are placed on estimates, coefficients can imply probabilities outside the unit interval. We focus on the marginal effects from the probit model estimation. These effects represent the marginal impact of an infinitesimal change in each independent continuous variable on the probability of self-employment, providing the most straight forward interpretation of estimated results from the probit models. For the dummy variables, the interpretations are slightly different as the estimates capture the marginal effect of a change in the probability of being self-employed for a particular group relative to the baseline group.

To test hypothesis 1 specifically, we estimate equation 2 and test for significant differences in the estimates of the probability of being on welfare for the different groups in matrix R. We test this hypothesis first assuming thee unrestricted measure of welfare and then the restricted measure of welfare. We test hypothesis 1 in two ways. First, we compare the probability of welfare usage of immigrant groups to U.S. born. In this analysis we are unable to control for length of stay in the U.S. This is because this variable is nonapplicable for native born American and including 0 for this group will distort the estimate. To try to control for the impact of wave of immigration, we include a dummy for immigration cohort and make native born Americans the baseline group for 
comparison. The use of immigrant cohort dummy is helpful but does not completely deal with the problem of the impact of years in the U.S. on welfare usage given the role of information in welfare usage, which is significantly correlated with length of stay. To deal with this problem, the second way we test hypothesis 1 is to eliminate those who are U.S. born from the analysis and compare the probability of welfare usage solely among immigrants. In this analysis, the probability of welfare usage for other immigrant birthplace groups is compared to immigrants with a European birthplace. In this analysis we can control for the years in the U.S., which is a one of the expected variables in the X matrix.

To test hypothesis 2 we estimate the probability of using welfare for the different groups first before reform (1995 survey) and after reform (1996-2007). We can only make use of one year prereform because the question of place of birth was only fully implemented from the 1995 CPS survey. Using these estimated probabilities, we compute the change in welfare usage for U.S. born and compare it to change in welfare usage for each immigrant group.

To test the final hypotheses (3a-3c), we restrict our sample to only U.S. citizens first and estimate the probability of welfare usage for all naturalized immigrant groups and citizens from protectorates in comparison to U.S. born. Next, we eliminate naturalized Americans and limit the sample to U.S. born and noncitizen immigrants and estimate the probability of welfare usage for noncitizen immigrants in comparison to U.S. born. We then compare the difference in welfare usage of naturalized Americans to the welfare usage of noncitizen immigrants. Given this analysis does not allow us to control for years in the U.S., again we redo this analysis excluding native born Americans and compare welfare usage among naturalized immigrants groups and subsequently we compare welfare usage for non citizen immigrants. In these latter two analysis, the base group for comparison are immigrants from Europe.

\section{Results}

Table 4 captures the estimation of the probit model on the sample population using both measures of welfare: the all inclusive measure and the restrictive measure. We present the marginal impact of the probit estimation for ease of interpretation. We use these estimates to test the first hypothesis. In column (1) and (3) we focus on the entire sample and the base group for comparison is U.S. 
born. In contrast, in column (2) and (4) we focus solely on the immigrant population, including immigrants from U.S. territories. In this estimation we control for years since immigration, which may also impact the likelihood of welfare usage. At the bottom of Table 4 we highlight the estimates of some of the variables we use as controls in the welfare usage probability model and also mention other variables we control for including eduction and health. The results using both measures of welfare are different but the conclusion in testing the hypothesis of interest is the same. The results in Table 4 show that despite controls for what should typically predict welfare usage, welfare usage is conspicuously higher for certain groups. Immigrants from U.S. protectorate like Puerto Rico, Guam and U.S. virgin Islands have the highest probability of any group using any form of welfare. With both measures of welfare we reject the hypothesis of similar welfare usage across groups based on birth place continents. Although immigrants from South America, Canada (other North America), Oceania and Europe use any form of welfare at the same rate as U.S. born, immigrants from Asia, Africa, Central American and U.S. protectorates use welfare more 1 The result in columns (2) and (4) confirm this finding of differential welfare usage among birthplace continent using the data restricted to solely immigrants. It also highlights the importance of including a control for length of stay. Notice that the result using the unrestricted welfare measure suggests that among immigrant groups, only immigrants from Europe and South America share identical probability of welfare usage. Other immigrant groups have higher probability of welfare than Europeans apart from immigrants from Canada who have the lowest probability of welfare usage among immigrant groups.

It is worth noting that focusing on the restricted or standard welfare measure, provides slightly different results for immigrants from Oceania and Europe. The result from column (3) suggests that Oceania and Canadian immigrants are $1 \%$ less likely to use any standard welfare than individuals who are U.S. born. They are the only groups with a lower probability of welfare usage than U.S. born. In contrast, while Europeans immigrants are equally as likely to use any type of welfare as U.S. born, they have a $0.6 \%$ higher probability of using standard welfare than U.S. born. In addition they are more likely to use standard welfare than immigrants from Oceania, Canada and South America. Also using this standard measures of welfare, the results from Table 1 shows that though

\footnotetext{
${ }^{1}$ Hence forth I will refer to other North America as Canada because the bulk of the immigrants that fall under this category are from Canada. However this group includes those from Bermuda.
} 
immigrants from Asia, Africa and North America are still more likely to be on welfare than U.S. born individuals, the gap is much smaller than with the unrestricted welfare measure. Given the results in Table 1, we reject the hypothesis that welfare usage is identical across immigrants and U.S. born and also reject the related hypothesis $1 \mathrm{~b}$ that welfare usage is identical for immigrant groups. Although some immigrant groups have identical welfare usage rates as summarized in column (2) and (4), the results suggest that some immigrant groups use welfare more. It is worth mentioning that the probability of welfare usage for immigrants from U.S. protectorates is significantly higher than every other group. Specifically, the probability of welfare usage for immigrants from U.S. protectorates is 9.9 percentage point higher than the next highest immigrant group (Africa) in terms of probability of welfare usage 2

The results in Table 5 and Table 6 summarizes the result of several estimations that allows us test our second main hypothesis. The results in Table 5 summarize our finding using the non restrictive measure of welfare while the results in Table 6 highlights our finding using the standard or restricted welfare usage measure. In both Table 5 and 6 columns (1) and (2), we focus on the whole sample while in columns (4) and (5) the focus is solely on immigrants. columns (1) and (4) provide the pre-reform estimates of the probability of welfare usage while columns (2) and (5) provides the after reform estimate. Recall that with our second hypothesis, we predict that given welfare reform led to an increase in restriction on welfare usage by immigrants who not citizens, then post reform the probability of using welfare should decrease for all immigrant groups in comparison to U.S. born, ceteris paribus. However among immigrants, welfare usage should decrease equally for comparable individuals regardless of birth place continent.

The results in columns (1), (2) and (3) allows us to test the first part of this hypothesis using the unrestricted welfare measures. From Table 5 it is clear that our hypothesis is rejected. All immigrant groups increased probability of welfare usage in comparison to U.S. born post welfare reform. Prior to the reform, all groups had a lower probability of being on welfare than U.S. born with immigrants from Central America and the Caribbean having the lowest probability (a 10\% lower probability). The Post-reform saw drastic changes in the usage of the welfare. Immigrants from Europe, Oceania, South America and Central American and the Caribbeans all have similar

\footnotetext{
${ }^{2}$ Africa only has a 4.1 percentage point higher probability of welfare usage than the base group Europe.
} 
welfare usage probability as U.S. born while immigrants from Africa and Asia now have a higher probability of being on welfare than U.S. born. Note that the estimates in Table 5 columns (2) and (5) are similar to those in Table (4), columns (1) and (2). The only difference is that we do not control for health status in the estimations of welfare usage in Table 5 and 6 because health status is not available in the pre reform period data. Interestingly, the differences in this estimate though not substantial suggests that health is a determinant of welfare usage. The estimates in columns (3) is direct evidence leading to the rejection of hypothesis 2. The positive coefficient indicates welfare usage increases versus decline. To test the related hypothesis that the change in welfare usage should be similar across immigrant groups, we turn to the results in Table 5 column (6). Given the change in welfare usage for other immigrant groups in comparison to European immigrants differ statistically, we reject hypothesis $2 \mathrm{~b}$. Our results suggest that while immigrants from Africa and Oceania have increased welfare usage probability more than those from Europe, immigrants from Asia, South America, Canada and Central America have increased the probability of welfare usage less than immigrants from Europe.

The results using the standard or restrictive measure of welfare in Table 6 confirm the results in Table 5. Pre-reform, standard welfare usage for all immigrant groups was less than U.S. born while post reform, the use of standard welfare increased for all immigrants groups with immigrants from Africa, Asia, Europe all with higher probability of using a standard welfare program than U.S. born. Comparing the change in welfare usage probabilities in column (3), Table 5 and 6 suggest that immigrants increased welfare usage for all types of welfare. However, notice that the increase in probability of standard welfare usage is smaller for all immigrant groups than the increase in the unrestricted welfare usage probability. Also using the standard welfare measure, our results in Table 6 columns (4)- (6) confirms results in Table 5 that changes in welfare usage for immigrant groups differed, with African immigrant groups experiencing the highest increase.

In terms of which immigrant group increased welfare usage the most or the least, we turn to the results in column (6) in Table 5 and 6 . Increases in welfare usage seems highest for immigrants from Africa and lowest for immigrants from U.S. protectorates. We test these changes for significant difference across groups and note that changes post reform was significantly different across groups but not significantly different for all groups. For example, the change in U.S. protectorates in 
probability of welfare usage was statistically different from the change in South America, Africa or Oceania. These results are unexpected and could imply a number of issues which we highlight next.

\subsection{Possible Reasons for Rejection of Hypothesis 2}

The test of the first hypothesis led to the rejection of the thesis that welfare usage should not differ across groups. This result suggests that welfare usage is not affected by solely economic and standard demographic. This implies that culture, value, network information or institutions of groups might have a significant role to play in individuals choice to use welfare. Culture, values, network information and institutional background were not controlled for in our probability model and may explain the differential welfare usage across group despite controlling for the standard economic and demographic variables that should predict welfare usage.

In contrast to the first hypothesis where our results may be explained by not including some social controls, the rejection of the second hypothesis is more unexpected. The theoretical expectation and prediction given an increase in restriction on welfare usage should be decreased usage. However with both measures of welfare usage, we see an increase in probability of welfare usage for all groups in comparison to the U.S. and differential increases across immigrant groups. One possible reason for this reverse result is the change in the population of immigrants over time. Post 1994, the sample of immigrants to the U.S. has changed significantly both in country of origin distribution and types of individuals (high skill, medium skill, low skill). Before 1990 most immigrants to the U.S. came in based on either based on family reunification, marriage and schooling. However, in the early 90s the U.S. government implemented the diversity visa lottery. The inception of the diversity visa lottery (D.V lottery) in 1995 provided another avenue through which families from most countries in the world meeting some criteria could immigrate to the U.S. as permanent residents. From 1995 when the first 40,301 gained entrance into the U.S. through this means, every year 55,000 more people from selected countries all over the world are issued this immigration visa. This types of people may share different values, perceptions and view than early immigrants and hence may act differently with respect to welfare usage, all other things being equal. Also post 1990 the number of immigrants moving to the U.S. based on refugee and asylum increased. This increase was precipitated by an increase in wars and civil conflicts in different parts of the world especially in Africa. Again though we control for income, the perception, attitude or view of these select groups of individuals given 
there experiences could be different and this may explain our surprising result. Also, given the visa lottery changed the distribution of immigrants across countries from each continent, then it makes sense that the average perception or values coming from each continent could changed over time. In addition, though we control for education, education acquired outside the U.S. especially in LDCs is not as good a predictor of income in the U.S. as education acquired in the U.S. This again may partly explain the increases likelihood of welfare usage despite this control. However the increase in probability of usage for immigrants from developed countries also, for which the transferability of education is less tenable, suggests that education transferability cannot be the only explanation for this reverse result. It is important to note that this finding is not implying that usage of welfare has increased or the proportion of people on welfare have increased for immigrants. Specifically, figure 1 shows that the proportion of people on welfare has fallen over time post reform for immigrants more than for citizens and the proportion of immigrants on welfare is slightly less than the proportion of U.S. born on welfare presently. This figure suggests that the reform did reduce immigrants welfare usage share as expected. However, our result shows that this policy did not reduce but rather increased the probability of welfare usage for immigrants who still qualified to get government assistant. In addition, our findings suggest that for comparable individuals, the choice of welfare seems to have changed for immigrants. Prior to reform, immigrants were less likely than U.S. born to use welfare and now post reform, immigrants are more likely to use welfare. However this result could be driven by the changes in immigrant types overtime.

To check if the change in the immigration population is driving the unexpected results of increase in probability of welfare usage post reform, we redo the post reform analysis restricting the sample of immigrants to those who were already in the U.S. by 1995. Results for this robustness analysis are summarized in Table 7. Although the estimates change, our inference and conclusions using this restricted sample of immigrants is still the same. Meaning we still reject hypothesis 2 . However it is important to highlight some differences in the results. Though the probability of using welfare in comparison to U.S. born increased for all immigrant groups, the increase is less pronounced for most immigrant groups than the earlier regression seemed to suggest. This is especially true for Asian and African immigrants. For these two groups, the use of welfare post 1996 is similar to U.S. born for immigrants who arrived before 1996 while an inclusion of all immigrants suggests a higher 

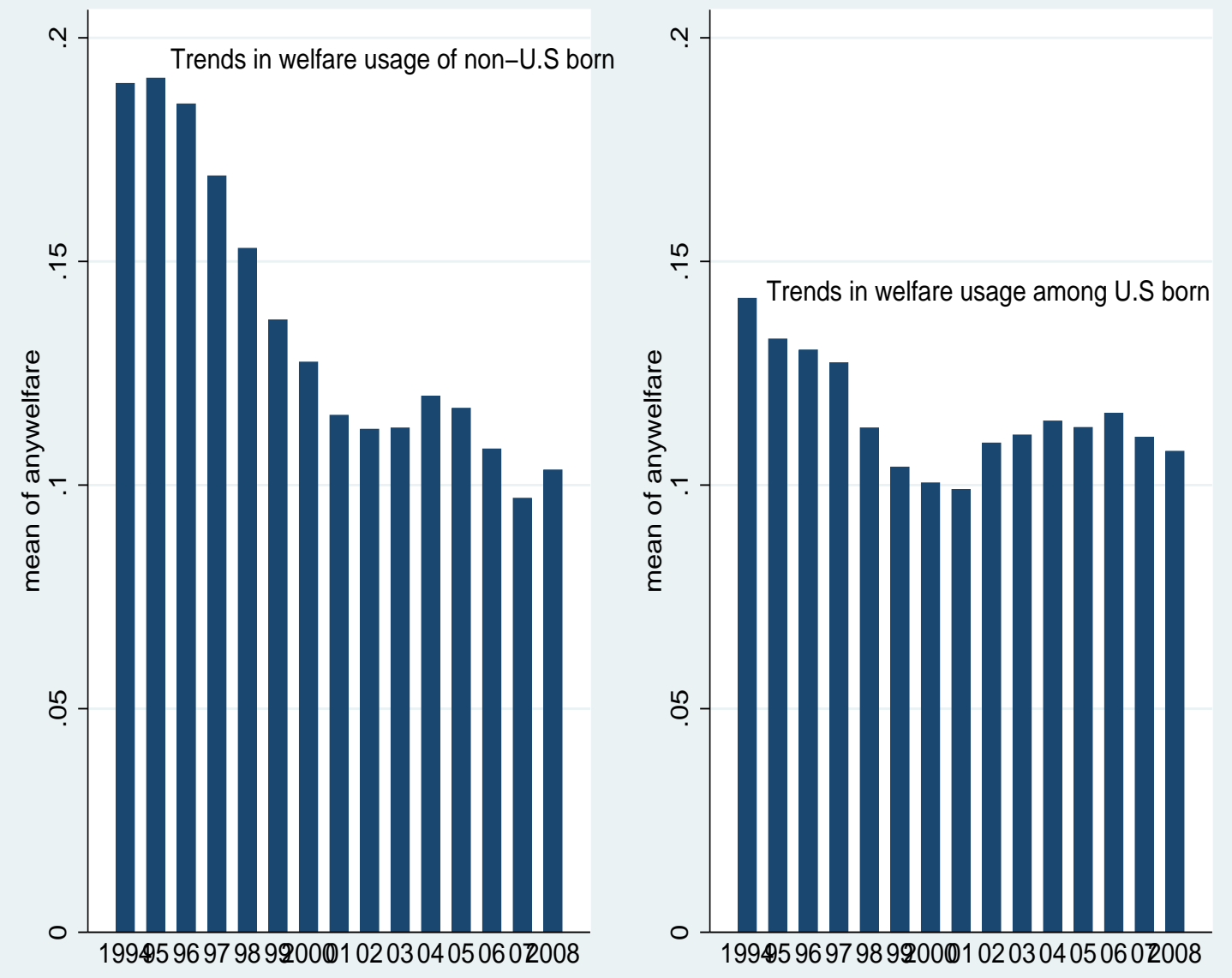

Figure 1: Trends in Welfare Usage for Immigrants and U.S born

Note: The $X$ axis shows the years and proportion using welfare is on $Y$ axis. 
probability of welfare usage in comparison to U.S. born post reform. For immigrants from Canada and South America the results do not change from those in Table 5. Interestingly, U.S. protectorates and immigrants from the Central America and Caribbeans are the only group with higher increase in the probability of welfare usage for its immigrant arriving before 1996 in comparison to all its immigrants, post reform. For immigrants from U.S. protectorates who are all eligible to use welfare, this result may imply a change in types of immigrants from these territories post 1996 or a change in the perception of welfare usage for more recent immigrant cohorts. However for immigrants from Central America and Caribbean, this result is more likely a reflection of the large increase in illegal immigrants from this region in the late 90s who are all not eligible for welfare programs. Hence a higher increase in probability of welfare usage for pre 1996 immigrants from this region in comparison to post 1996 immigrants from this region could simply reflects a decrease in eligibility distribution among post 1999 immigrants from Central America and the Caribbeans.

The results in Table 7 provide support for our thesis that part of the noted increase in the probability of welfare usage is solely driven by change in immigrant population post 1996. However, the result in Table 7 shows that change in immigrant population is not the only factor that has led to this increased probability in comparison to U.S. born. One possible explanation for the increased probability among immigrants who arrived before 1996 could be that the welfare reform and the media coverage that came with it provided ample information on welfare eligibility that might not have been available among some immigrant communities before the reform. This increase in information could lead to an increase in usage for those who were eligible prior to reform but were not aware of it. Hence increased information as was available through the welfare program overhaul could have led to an increase in usage for those eligible despite the decrease usage for immigrant who were no longer eligible for welfare. The net effect from these two opposing forces could be an increase probability of welfare usage for immigrant groups in comparison to U.S. born. It is also possible that the introduction of welfare reform led to an increase in welfare usage among eligible immigrants who did not use welfare previously just to help their relations and community of recent immigrant who were no longer eligible to get welfare benefits because of the reform. Implying that within immigrant communities, a form of transfer system could have emerged as a response to the reform. Meaning those who are eligible and previously did not use welfare, now take advantage of 
welfare only to support those who are not eligible within the community and need support which they can no longer get from the government.

The finding highlighted in Tables (4)-(7) above could be downwards biased with respect to revealing the true preference for welfare usage among immigrants. This is because though we have a revealed preference for U.S. born Americans with regards to welfare usage, we do not have a revealed preference for a good portion of immigrants. Immigrants who are not permanent residents and U.S. citizens are not eligible for most government assistance. Even those who are permanent residents are restricted in their access for a certain number of years post 1996. Hence, the fact that the share of immigrants on welfare is dropping does not tell us anything about the true preference of immigrants for welfare use.

One way to get around this problem and ensure that we get a sense of the true preference for welfare usage for immigrants, is to compare U.S. born Americans to immigrants whose preference are revealed. To implement this, we restrict the sample of immigrants to solely those who are naturalized. In addition, decomposing the set of immigrants into those who are citizens and those who are not will also help us in testing our third hypothesis. Our third hypothesis has three separate parts. Each of these sub hypothesis are tested though our decomposition of immigrants and estimating the probability of welfare usage for citizen immigrants in comparison to U.S. born. These results are in column (1) Table 8 and 9. Subsequently, we focus on noncitizen immigrants, comparing them with U.S. born. This result is summarized in column (2) of both Tables 8 and 9. Table 8 captures the result using the nonrestricted welfare measure while Table 9 summarizes the result using the restricted measure of welfare.

The results are again interesting and quite unexpected if only economic or demographic factors are supposed to matter as predictors of welfare usage. We reject hypothesis $3 \mathrm{a}$. We find that Naturalized Americans on average have a lower probability of welfare usage than Noncitizen immigrants and not a higher probability. Notice from Table 8 column (1) and (2) that all naturalized American have equal or lower probability of welfare usage than U.S. born 3 In contrast, noncitizen immigrants from Asia, Africa, Oceania, Central American and the Caribbean, Europe have a higher probability of welfare usage than U.S. born immigrants while noncitizen immigrants from Canada and South

\footnotetext{
${ }^{3}$ We do not show immigrants from US protectorates in this analysis because they are neither naturalized or non citizen immigrants. We already have shown that they use welfare at a much higher rate than U.S. born.
} 
America have a similar probability of welfare usage as U.S. born 4 Interestingly, if we compare naturalized immigrant solely among themselves, the results in Table 8 column (4) suggests differential welfare usage among naturalized immigrant groups. In comparison to naturalized immigrants from Europe, all other naturalized immigrant use welfare slightly more apart from those from Oceania and Canada who have similar probability of welfare use as naturalized immigrants from Europe. For noncitizen immigrants the results are slightly different. In comparison to noncitizen immigrants from Europe, some nonimmigrant groups use welfare slightly more, while South America and Canada use welfare slightly less. Only those from Oceania have similar probability of welfare use as noncitizen immigrants from Europe.

The results from Table 9 using the restricted measure of welfare is slightly different from the results using the unrestricted measure of welfare in Table 8. However it also leads to a rejection of hypothesis 3a, naturalized Americans do not have a higher probability of being on welfare than immigrant who are noncitizens. We also reject hypothesis $3 \mathrm{~b}$ based on the results in Tables 9 . The use of standard welfare is not similar for all comparable noncitizens from different birth place and similarly, the probability of welfare usage is not identical for naturalized immigrant groups.

The results in Table 8 and 9 suggests that naturalized immigrants do not use welfare more than noncitizen immigrants, second welfare usage differ among both naturalized immigrants based on birth place and also differs among noncitizen immigrants.

\subsection{Robustness Check-Hypothesis 1}

Returning to the first hypothesis on does birthplace continent matter for welfare usage, we can retest this hypothesis focusing solely on those who are eligible for welfare usage. Recall in our earlier test of this hypothesis we did not address the issue of eligibility. Rather we estimated the likelihood of welfare usage for all immigrant birth place groups. However, given preferences are not revealed for those who are ineligible for welfare and these immigrants are included in the sample of all immigrants, then focusing solely on naturalized immigrants and citizens from U.S. protectorates

\footnotetext{
${ }^{4}$ The only group with higher probability of welfare usage is the group that consists of U.S. territories and naturalized citizens from Canada. However this higher welfare usage for this group is not driven by the naturalized immigrants from Canada but by immigrants from U.S. territories. If we isolate the Canadians naturalized immigrants, we actually find that naturalized Canadians have a similar probability of welfare as naturalized Americans from other group and U.S. born.
} 
in comparison to U.S. born should be more appropriate for testing hypothesis one. Looking again at table 8 and 9 column (1), which focus solely on naturalized immigrants and U.S. born leads to new conclusions. First, given preference for welfare is revealed for naturalized citizens the results for naturalized immigrants provides concrete evidence that immigrant birthplace matters for welfare usage. Hence we still reject hypothesis $1 \mathrm{~b}$. With respect to hypothesis $1 \mathrm{~A}$ we still reject the hypothesis that immigrants and U.S. born have similar welfare usage. Recall that true preference for welfare is revealed for three groups: U.S. born, U.S. protectorates citizens and naturalized citizens, and though U.S. born and naturalized citizens on average share similar probabilities of using welfare, immigrants from U.S. protectorates have a much higher welfare usage than U.S. born 5 A possible issue that could cloud the validity of this results is self selection. It is possible to argue that immigrants select to become naturalized citizens and the preference of naturalized for welfare usage could be very different for noncitizen immigrants even if we could observe their true welfare usage preference. Meaning that we cannot assume that comparable noncitzen immigrants will use welfare similarly to naturalized immigrants if welfare restrictions are lifted. Similarly, we cannot assume that providing citizenship for all noncitizen will lead to similar welfare usage for all immigrants and citizens.

\subsection{Other Results}

Also we can conclude from this result that using the restricted measure of welfare could be misleading. This implies that concentrating on the three main types of government assistance could lead to a biased opinion on welfare usage across immigration groups in the U.S. Notice from Table 8 that is seems naturalized immigrants from Asia use welfare more than those who are U.S. born and naturalized immigrants from Oceania seem to use welfare less. However, with the unrestricted measure all three groups share similar probabilities. Similarly, naturalized immigrants from Oceania seems to have lower probability of welfare usage as naturalized immigrants from Europe but in reality they have similar probability of welfare usage.

\footnotetext{
${ }^{5}$ Recall from Table 8 that for naturalized citizens, welfare usage is similar to U.S. born for naturalized immigrants from all birth places apart from Canada for which the probability of welfare usage is slightly less than U.S. born.
} 


\section{Possible Explanation for results: Culture, Values and Institutions or Self Selection}

Our results has led to several unexpected findings. First, the fact that American citizens from U.S. protectorates are more likely than any other group to use welfare is surprising. Second, finding that comparable individuals from some immigrant group have different probability of welfare usage. Third, we find that the probability of welfare usage increased post reform even for immigrants arriving before the reform. Fourth, for some birthplace groups, we find higher probability of welfare usage by noncitizen immigrants in comparison to naturalized Americans from the same group. These unexpected results could be driven by several factors. We will highlight possible explanation for these results, however we do not providing evidence for or against each of the potential explanation because this is beyond the scope of our paper.

First, culture, values and individuals' exposure to institutions are variables that economists traditionally do not consider because of the difficulty in quantifying these variables. However, it makes sense that a person's culture, value or experiences may affect the way they view the use of welfare or the individuals preference for or against governments help and assistance. We can view individuals cultural view of welfare usage as the preference of a group for government assistance. Given anecdotal evidence on different people groups perception on welfare usage in the U.S., it is not impossible to imagine that preference for welfare may differ across countries. This difference could be linked with institutional experiences or other factors. Second If we think of those who are naturalized as a select group who choose U.S. citizenship because of their allegiance or respect for the U.S. and their interest in serving or giving back or being totally part of this country, then these individuals are more likely not to use welfare if they do not absolutely need it. This may explain the lower welfare usage among naturalized immigrants for some birthplace groups in comparison to noncitizen immigrants from those continents despite the existence of restrictions on welfare usage on a portion of the latter (only permanent residents among noncitizen immigrants are eligible for some government assistance), which should typically lead to lower welfare usage for noncitizens. Third, it is possible that the increase in welfare usage post the reform, even among those who immigrated before the reform, may be due to the fact that some of those who were not eligible before 1996 for 
welfare, become eligible over time as they moved from visas to permanent residence status 6 Also as highlighted previously, it may be that the whole media coverage of the welfare reform provided a lot of information to groups who did not know much about welfare usage previously, which could lead to higher welfare usage. In addition as highlighted earlier also, eligible immigrant might be using welfare more post reform not for themselves but transferring benefits to other member of their community (extended family) who are not or no longer eligible for welfare programs but need assistance.

One argument against differences in culture and values in birthplace groups as it relates to welfare usage is that if differences in welfare usage can be explained by an immigrants' culture and values, and if culture and values are similar among immigrants from the same birthplace, then probability of welfare usage should be the same for naturalized and noncitizen immigrants from the same birth place whose preferences are revealed. However, our results indicate otherwise and suggests that either culture and value varies within countries/ birthplace groups, or other factors like information and experience have a role to play. Information and experience can differ within and between immigrant groups and can explain differences in probability of welfare usage for citizens and noncitizen immigrants from the same immigrant group. Given the extremely high use of welfare for citizens from U.S. protectorates in comparison to everyone else, it is possible that information has a role to play. The role of information and networks on welfare usage has been documented in the past. Immigrants from U.S. protectorates are U.S. citizens from birth and are more likely to have more information than immigrants from anywhere else. However, their access to information does not address the question of why they use welfare more than U.S. born Americans who should have the same or more information. Hence though information may be important for welfare usage, other factors still have a role to play in explaining our results.

\section{Conclusion and Inferences}

In this paper we try to answer three related questions by testing several simple hypotheses. First, we create a simple model that indicates that if only demographic and economic factors matter, we do not expect comparable individuals to use welfare at different rates. Hence, individuals birthplace

\footnotetext{
${ }^{6}$ Also recall that the law only made restriction on welfare usage for new permanent resident immigrants and not for permanent resident immigrants before 1996.
} 
should not matter for welfare usage. This is the basis of the first hypothesis we test. Second we argue that a change in policy that restricts welfare usage for non US citizens should lead to a decline in the probability of welfare usage for all immigrants in comparison to U.S. born. In addition, ceteris paribus, the decline in welfare usage for all immigrant groups should be similar as the reform did not create differential restrictions on immigrants based on place of birth. These expectation led to our second set of hypotheses. Our final hypothesis is based on the premise that naturalized immigrants and U.S. born Americans are the only groups whose true preferences for welfare are revealed post the 1996 reform. This is because the change in policy does not affect these groups. However, for noncitizen immigrants, especially those who are on visa and illegal, the fact they are not on welfare does not say anything about their preference or non-preference for welfare usage. Hence, we expect that the probability of welfare usage would be higher for naturalized immigrants compared to noncitizen immigrants simply because of the restriction on the latter.

Our results leads to the rejection of all our posed hypotheses. First our results show that though many immigrant groups have identical probabilities of welfare as U.S. born, not all do. Hence, birthplace matters for welfare usage in the U.S. In particular, our results suggest that immigrants from U.S. protectorates use welfare more than any other group. Second, counter to what we expected, our result suggest that despite a decline in the proportion of immigrants using welfare post welfare reform in 1996, the probability of welfare usage increased for all groups post reform in comparison to U.S. born. We show that this result is not driven solely by changes in immigrant population type over the last 10 years and immigrants arriving pre reform also experienced an increase in probability of welfare usage in comparison to the U.S. Our results also shows that this increase in probability of welfare usage post 1996 differs across immigrant groups. Lastly, we also find that in contrast to what we expect, naturalized immigrants on average use welfare less or equal to noncitizen immigrants.

What can we infer from these results or what do these results suggest? First, other non traditional factors may be important for welfare usage. The culture, institutions and values people share may shape their perception of welfare usage. In addition, peoples experiences and the information they have may affect their likelihood of welfare usage. All these factors were not controlled for in our probability model and could explain this unexpected result. Also the distribution of immigrant types from each continent has changed significantly over the $90 \mathrm{~s}$. The inception of the visa lottery and 
the increase in refugee immigrants from war torn countries in Africa and other parts of the world can partly explain this change in the distribution. This change in the distribution may explain part of the rise in probability of welfare usage post reform, although our results show that even among immigrants arriving before reform, a rise in probability is noted. It is important to note that our results do not suggest that welfare reform did not reduce welfare usage on average. Rather, we try to find explanation for our unexpected result. The immigrant population in the U.S. may have changed a lot over the last decade and if these new immigrants had different experiences or have different culture, institutions and values because they come from different countries within these continents, they may view welfare usage very differently.

In addition, the fact that naturalized immigrants from some continents use welfare less or the same as noncitizens (given the restriction on this group) may suggest first a selection process into being naturalized and may also suggest that this selection process may differ based on birthplace. Meaning that people selecting to become naturalized citizens may have different values and perception than other immigrants from the same continent, which may affect their decision not to use welfare.

Our finding suggest the need for much more research on the decision to use welfare or not. Clearly, other non traditional factors matter for welfare usage and being able to single out these factors will be of importance with respect to suggesting policy that will attenuate unnecessary welfare usage in the U.S. In future work, we hope to focus on immigrants from U.S. territories and try to identify the role of information and other factors in explaining the high welfare usage of this group in comparison to any other immigrant and citizen group. 


\section{References}

[1] Blau, Francine (1984). "The Use of Transfer Payments By Immigrants". Industrial and Labor Relations Review, vol. 37 pp. 222-239.

[2] Borjas, George (1994). "The Economics of Immigration", Journal of Economic Literature vol. XXXII, pp. 1667-1717.

[3] Borjas George and Trejo Stephen J. (1991). "Immigrant Participation In The Welfare System", Industrial and Labor Relations Review, vol. 44 issue 2.

[4] Borjas, G. J. (1999). "Immigration and welfare magnets." Journal of Labor Economics 17(4): 607-637.

[5] Borjas George and Lynette Hilton (1996) "Immigration and the Welfare State: Immigrant Participation in Means-Tested Entitlement Programs". The Quarterly Journal of Economics, vol. 111, issue 2, pages 575-604.

[6] Borjas J. George, (2000). "Immigration and the Food Stamp Program," JCPR Working Papers 121, Northwestern University/University of Chicago Joint Center for Poverty Research.

[7] Ekhaugen, Tyra, 2005. "Immigrants on Welfare: Assimilation and Benefit Substitution," Memorandum 18/2005", Oslo University, Department of Economics.

[8] Hansen, Jorgen, Lofstrom, Magnus (2003). "Immigrant Assimilation and Welfare Participation: Do Immigrants Assimilate Into or Out of Welfare? J. Human Resources XXXVIII: 74-98.

[9] Hao, Lingxin and Yukio Kawano. 2001. "Immigrants' Welfare Use and Opportunity for Coethnic Contact." Demography 38:375-389.

[10] Huffman, Sonya Kostova and Kilkenny Maureen (2003). Regional Welfare Programs and Labor Force Participation. Staff General Research Papers from Iowa State University, Department of Economics.

[11] Kaushal, Neeraj (2005). "New Immigrants' Location Choices: Magnets without Welfare," Journal of Labor Economics, University of Chicago Press, vol. 23(1), pages 59-80, January. 
[12] Kazemipur Abdolmohammed and Halli S. Shiva (2001). "Immigrants and the 'New Poverty': The Case Of Canada", International Migration Review, Vol. 35 Number 4 pp. 1129-1156.

[13] Lofstrom, Magnus and Bean Frank D (2002). "Assessing Immigrant Policy Options: Labor Market Conditions and Postreform Declines in Immigrants' Receipt of Welfare". Demography, Volume 39-Number 4, November 2002: 617-637.

[14] Lofstrom Magnus and Hansen Jrgen (2006). "Immigrant-Native Differences in Welfare Participation:The Role of Entry and Exit Rates" Institute for the Study of Labor, IZA DP No. 2261.

[15] Zavodny, Madeline (1997). "Welfare and the locational choices of new immigrants. Economic and Financial Policy Review, issue Q II, pages 2-10. 
Table 3: Welfare Usage by Immigration Status and Birth Place

\begin{tabular}{|c|c|c|c|c|}
\hline Birthplace & & $\begin{array}{c}\text { Naturalized } \\
(1)\end{array}$ & $\begin{array}{c}\text { Non-naturalized } \\
(2)\end{array}$ & $\begin{array}{c}\text { U.S. born } \\
(3) \\
\end{array}$ \\
\hline \multirow[t]{3}{*}{ Africa } & Mean & 0.074 & 0.15 & \\
\hline & Stand. Dev. & $(0.26)$ & $(0.36)$ & \\
\hline & $\mathrm{N}$ & 2864 & 4355 & \\
\hline \multirow{3}{*}{$\begin{array}{c}\text { Central America } \\
\text { \& Caribbean }\end{array}$} & Mean & 0.14 & 0.15 & \\
\hline & Stand. Dev. & $(0.34)$ & $(0.36)$ & \\
\hline & $\mathrm{N}$ & 35628 & 103928 & \\
\hline \multirow[t]{3}{*}{ Asia } & Mean & 0.077 & 0.10 & \\
\hline & Stand. Dev. & $(0.27)$ & $(0.30)$ & \\
\hline & $\mathrm{N}$ & 30521 & 31317 & \\
\hline \multirow[t]{3}{*}{ Europe } & Mean & 0.065 & 0.094 & \\
\hline & Stand. Dev. & $(0.25)$ & $(0.29)$ & \\
\hline & $\mathrm{N}$ & 18113 & 15051 & \\
\hline \multirow[t]{3}{*}{ South America } & Mean & 0.085 & 0.087 & \\
\hline & Stand. Dev. & $(0.27)$ & $(0.28)$ & \\
\hline & $\mathrm{N}$ & 7066 & 12362 & \\
\hline \multirow[t]{3}{*}{ Oceania } & Mean & 0.071 & 0.14 & \\
\hline & Stand. Dev. & $(0.26)$ & $(0.35)$ & \\
\hline & $\mathrm{N}$ & 464 & 877 & \\
\hline \multirow[t]{3}{*}{ Other } & Mean & 0.1 & 0.17 & \\
\hline & Stand. Dev. & $(0.3)$ & $(0.38)$ & \\
\hline & $\mathrm{N}$ & 3090 & 5098 & \\
\hline \multirow{3}{*}{$\begin{array}{l}\text { Other North } \\
\text { America }\end{array}$} & Mean & 0.063 & 0.052 & \\
\hline & Stand. Dev. & $(0.24)$ & $(0.22)$ & \\
\hline & $\mathrm{N}$ & 2627 & 3391 & \\
\hline \multirow[t]{3}{*}{ U.S. protectorates } & Mean & & & 0.34 \\
\hline & Stand. Dev. & & & $(0.473)$ \\
\hline & $\mathrm{N}$ & & & 16902 \\
\hline \multirow[t]{3}{*}{ Natives } & Mean & & & 0.12 \\
\hline & Stand. Dev. & & & $(0.32)$ \\
\hline & $\mathrm{N}$ & & & 1842647 \\
\hline
\end{tabular}

Standard Dev. -Standard Deviation 
Table 4: Does birth place matter for welfare usage?

\begin{tabular}{|c|c|c|c|c|}
\hline \multirow{2}{*}{$\begin{array}{c}\text { Independent } \\
\text { Variables }\end{array}$} & \multicolumn{2}{|c|}{ Unrestricted Welfare Measure } & \multicolumn{2}{|c|}{ Restricted Welfare Measure } \\
\hline & $\begin{array}{c}\text { anywelfare } \\
\text { (1) }\end{array}$ & $\begin{array}{c}\text { anywelfare } \\
\text { (excludes U.S. born) } \\
\text { (2) }\end{array}$ & $\begin{array}{l}\text { welfstandard } \\
\text { (3) }\end{array}$ & $\begin{array}{c}\text { welfstandard } \\
\text { (excludes U.S. born) } \\
\text { (4) }\end{array}$ \\
\hline \multirow{2}{*}{ U.S. Protectorate } & $0.085^{*}$ & $0.14^{*}$ & $0.051^{*}$ & $0.079^{*}$ \\
\hline & $(0.01)$ & $(0.006)$ & $(0.007)$ & $(0.004)$ \\
\hline \multirow[t]{2}{*}{ Other North America } & -0.005 & $-0.014^{*}$ & $-0.01 *$ & $-0.021^{*}$ \\
\hline & $(0.004)$ & $(0.004)$ & $(0.006)$ & $(0.002)$ \\
\hline \multirow[t]{2}{*}{ C.A.C } & $0.008^{*}$ & $0.03^{*}$ & 0.004 & $0.014^{*}$ \\
\hline & $(0.004)$ & $(0.002)$ & $(0.003)$ & $(0.002)$ \\
\hline \multirow[t]{2}{*}{ South America } & -0.002 & -0.0003 & -0.003 & $-0.008^{*}$ \\
\hline & $(0.004)$ & $(0.003)$ & $(0.002)$ & $(0.002)$ \\
\hline \multirow[t]{2}{*}{ Europe } & 0.004 & & $0.007^{*}$ & \\
\hline & $(0.004)$ & & $(0.003)$ & \\
\hline \multirow{2}{*}{ Asia } & $0.018^{*}$ & $0.022^{*}$ & $0.012^{*}$ & $0.010^{*}$ \\
\hline & $(0.005)$ & $(0.002)$ & $(0.004)$ & $(0.002)$ \\
\hline \multirow[t]{2}{*}{ Africa } & $0.023^{*}$ & $0.041^{*}$ & $0.008^{*}$ & $0.014^{*}$ \\
\hline & $(0.006)$ & $(0.005)$ & $(0.004)$ & $(0.004)$ \\
\hline \multirow{2}{*}{ Oceania } & 0.008 & $0.019^{*}$ & $-0.010^{*}$ & $-0.016^{*}$ \\
\hline & $(0.008)$ & $(0.01)$ & $(0.003)$ & $(0.004)$ \\
\hline \multirow[t]{2}{*}{ Others } & $0.018^{*}$ & $0.036^{*}$ & $0.009^{*}$ & $0.017^{*}$ \\
\hline & $(0.006)$ & $(0.006)$ & $(0.004)$ & $(0.003)$ \\
\hline \multirow[t]{3}{*}{ age } & $-0.001^{*}$ & $0.000^{*}$ & $0.000^{*}$ & $0.000^{*}$ \\
\hline & $(0.00)$ & $(0.00)$ & $(0.00)$ & $(0.00)$ \\
\hline & -41.780 & 6.140 & -46.400 & 6.500 \\
\hline \multirow[t]{2}{*}{ sex } & $0.006^{*}$ & $-0.005^{*}$ & $0.004^{*}$ & $-0.004^{*}$ \\
\hline & $(0.0003)$ & $(0.001)$ & $(0.0002)$ & $(0.001)$ \\
\hline \multirow[t]{2}{*}{ famsize } & $-0.005^{*}$ & $-0.003^{*}$ & $-0.001^{*}$ & $0.001^{*}$ \\
\hline & $(0.0001)$ & $(0.0003)$ & $(0.000)$ & $(0.00)$ \\
\hline \multirow[t]{2}{*}{ children } & $0.027^{*}$ & $0.024^{*}$ & $0.017^{*}$ & $0.017^{*}$ \\
\hline & $(0.000)$ & $(0.001)$ & $(0.000)$ & $(0.001)$ \\
\hline \multirow[t]{2}{*}{ def income } & 0.000 & 0.000 & 0.000 & 0.000 \\
\hline & $(0.00)$ & $(0.00)$ & $(0.000)$ & $(0.00)$ \\
\hline \multirow[t]{2}{*}{ yrs in the U.S. } & no & $-0.0009^{*}$ & no & $-0.001^{*}$ \\
\hline & & $(0.000)$ & & $(0.009)$ \\
\hline State Dum & yes & yes & yes & yes \\
\hline Year Dum & yes & yes & yes & yes \\
\hline Employment & yes & yes & yes & yes \\
\hline Immigrant cohort & yes & no & yes & no \\
\hline Married Dum & yes & yes & yes & yes \\
\hline Health Dum & yes & yes & yes & yes \\
\hline Educ & yes & yes & yes & yes \\
\hline
\end{tabular}

Note: estimates are marginal impacts from probit estimation

C.A.C- Central America and the Caribbeans

* $5 \%$ significance level

Dependent variable is welfare usage 
Table 5: What was the effect of the reform on welfare usage across groups [Unrestricted Welfare Measure]

\begin{tabular}{|c|c|c|c|c|c|c|}
\hline Variables & $\begin{array}{c}\text { anywelfare } \\
(1) \\
\end{array}$ & $\begin{array}{c}\text { anywelfare } \\
(2) \\
\end{array}$ & $(3)$ & $\begin{array}{c}\text { anywelfare } \\
\text { (excludes U.S. born) } \\
(4)\end{array}$ & $\begin{array}{c}\text { anywelfare } \\
\text { (excludes U.S. born) } \\
(5)\end{array}$ & $(6)$ \\
\hline & before reform & postreform & change & before reform & postreform & change \\
\hline U.S. Protectorates & $\begin{array}{c}-0.068^{*} \\
(0.001)\end{array}$ & $\begin{array}{l}0.094^{*} \\
(0.011)\end{array}$ & 0.162 & $\begin{array}{l}0.239^{*} \\
(0.024)\end{array}$ & $\begin{array}{l}0.147^{*} \\
(0.005)\end{array}$ & -0.092 \\
\hline Other North America & $\begin{array}{c}-0.067^{*} \\
(0.001)\end{array}$ & $\begin{array}{l}-0.008 \\
(0.004)\end{array}$ & 0.067 & $\begin{array}{l}-0.014 \\
(0.021)\end{array}$ & $\begin{array}{c}-0.017^{*} \\
(0.004)\end{array}$ & -0.017 \\
\hline C.A.C & $\begin{array}{c}-0.104^{*} \\
(0.003)\end{array}$ & $\begin{array}{l}0.009^{*} \\
(0.005)\end{array}$ & 0.113 & $\begin{array}{l}0.085^{*} \\
(0.012)\end{array}$ & $\begin{array}{l}0.034^{*} \\
(0.002)\end{array}$ & -0.051 \\
\hline South America & $\begin{array}{c}-0.068^{*} \\
(0.001)\end{array}$ & $\begin{array}{l}-0.002 \\
(0.004)\end{array}$ & 0.068 & $\begin{array}{l}-0.004 \\
(0.016)\end{array}$ & $\begin{array}{l}-0.002 \\
(0.003)\end{array}$ & 0.00 \\
\hline Europe & $\begin{array}{c}-0.081^{*} \\
(0.002)\end{array}$ & $\begin{array}{c}0.004 \\
(0.005)\end{array}$ & 0.081 & & & \\
\hline Asia & $\begin{array}{c}-0.080^{*} \\
(0.002)\end{array}$ & $\begin{array}{l}0.020^{*} \\
(0.006)\end{array}$ & 0.100 & $\begin{array}{c}0.067^{*} \\
(0.015)\end{array}$ & $\begin{array}{l}0.023^{*} \\
(0.002)\end{array}$ & -0.044 \\
\hline Africa & $\begin{array}{c}-0.065^{*} \\
(0.001)\end{array}$ & $\begin{array}{l}0.024^{*} \\
(0.007)\end{array}$ & 0.089 & $\begin{array}{c}0.043 \\
(0.045)\end{array}$ & $\begin{array}{l}0.042^{*} \\
(0.005)\end{array}$ & 0.042 \\
\hline Oceania & $\begin{array}{c}-0.064^{*} \\
(0.001)\end{array}$ & $\begin{array}{c}0.007 \\
(0.008)\end{array}$ & 0.064 & $\begin{array}{c}-0.090^{*} \\
(0.019)\end{array}$ & $\begin{array}{l}0.015 \\
(0.01)\end{array}$ & 0.090 \\
\hline Others & $\begin{array}{c}-0.070^{*} \\
(0.001)\end{array}$ & $\begin{array}{l}0.019^{*} \\
(0.006)\end{array}$ & 0.089 & $\begin{array}{l}0.034^{*} \\
(0.018)\end{array}$ & $\begin{array}{l}0.039^{*} \\
(0.006)\end{array}$ & 0.005 \\
\hline Sex & $\begin{array}{c}0.003 \\
(0.002)\end{array}$ & $\begin{array}{l}0.006^{*} \\
(0.00)\end{array}$ & & $\begin{array}{l}-0.009 \\
(0.006)\end{array}$ & $\begin{array}{c}-0.005^{*} \\
(0.001)\end{array}$ & \\
\hline no child & $\begin{array}{l}0.043^{*} \\
(0.001)\end{array}$ & $\begin{array}{l}0.028^{*} \\
(0.000)\end{array}$ & & $\begin{array}{l}0.041^{*} \\
(0.003)\end{array}$ & $\begin{array}{l}0.024^{*} \\
(0.001)\end{array}$ & \\
\hline years in USA & no & no & & yes & yes & \\
\hline State Dum & yes & yes & & yes & yes & \\
\hline Year Dum & no & yes & & no & yes & \\
\hline Employment & yes & yes & & yes & yes & \\
\hline Immigrant cohort & yes & yes & & no & no & \\
\hline Married Dum & yes & yes & & yes & yes & \\
\hline Health Dum & no & no & & no & no & \\
\hline Educ Dum & yes & yes & & yes & yes & \\
\hline Wages & yes & yes & & yes & yes & \\
\hline Family size & yes & yes & & yes & yes & \\
\hline age & yes & yes & & yes & yes & \\
\hline
\end{tabular}

Note: estimates are marginal impacts from probit estimation

C.A.C- Central America and the Caribbeans

* $5 \%$ significance. Note: Estimates that are not significant are treated as 0 in calculating the difference between columns (1) and (2) and between (4) and (5) highlighted in column (3) and (6). 
Table 6: What was the effect of the reform on welfare usage across groups ? [Restricted Welfare Measure]

\begin{tabular}{|c|c|c|c|c|c|c|}
\hline \multirow{2}{*}{$\begin{array}{c}\text { Independent } \\
\text { Variable: }\end{array}$} & \multicolumn{2}{|c|}{$\overline{\mathrm{ALL}}$} & \multirow{2}{*}{$\begin{array}{c}\text { Difference } \\
\text { change } \\
(3)\end{array}$} & \multicolumn{2}{|c|}{ Only Immigrants } & \multirow{2}{*}{$\begin{array}{c}\text { Difference } \\
\text { change } \\
(6)\end{array}$} \\
\hline & $\begin{array}{l}\text { welfstandard } \\
\text { (1) }\end{array}$ & $\begin{array}{l}\text { welfstandard } \\
\text { (2) }\end{array}$ & & $\begin{array}{c}\text { welfstandard } \\
\text { (excludes U.S. born) } \\
(4)\end{array}$ & $\begin{array}{c}\text { welfstandard } \\
\text { (excludes U.S. born) } \\
(5)\end{array}$ & \\
\hline & before reform & postreform & change & before reform & postreform & change \\
\hline US protectorates & $\begin{array}{c}-0.041^{*} \\
(0.001)\end{array}$ & $\begin{array}{l}0.058^{*} \\
(0.008)\end{array}$ & 0.099 & $\begin{array}{l}0.159^{*} \\
(0.021)\end{array}$ & $\begin{array}{l}0.085^{*} \\
(0.005)\end{array}$ & -0.074 \\
\hline Other North America & $\begin{array}{c}-0.041^{*} \\
(0.001)\end{array}$ & $\begin{array}{l}-0.012^{*} \\
(0.002)\end{array}$ & 0.029 & $\begin{array}{c}-0.039^{*} \\
(0.021)\end{array}$ & $\begin{array}{l}-0.022^{*} \\
(0.002)\end{array}$ & 0.017 \\
\hline C.A.C & $\begin{array}{c}-0.066^{*} \\
(0.003)\end{array}$ & $\begin{array}{c}0.005 \\
(0.003)\end{array}$ & 0.066 & $\begin{array}{l}0.045^{*} \\
(0.010)\end{array}$ & $\begin{array}{l}0.016^{*} \\
(0.002)\end{array}$ & -0.035 \\
\hline South America & $\begin{array}{l}-0.042^{*} \\
(0.001)\end{array}$ & $\begin{array}{l}-0.004 \\
(0.003)\end{array}$ & 0.042 & $\begin{array}{l}-0.011 \\
(0.012)\end{array}$ & $\begin{array}{l}-0.007^{*} \\
(0.002)\end{array}$ & -0.007 \\
\hline Europe & $\begin{array}{c}-0.050^{*} \\
(0.002)\end{array}$ & $\begin{array}{l}0.007^{*} \\
(0.004)\end{array}$ & 0.057 & & & \\
\hline Asia & $\begin{array}{l}-0.050^{*} \\
(0.002)\end{array}$ & $\begin{array}{l}0.013^{*} \\
(0.004)\end{array}$ & 0.063 & $\begin{array}{l}0.038^{*} \\
(0.012)\end{array}$ & $\begin{array}{l}0.010^{*} \\
(0.002)\end{array}$ & -0.028 \\
\hline Africa & $\begin{array}{c}-0.040^{*} \\
(0.001)\end{array}$ & $\begin{array}{l}0.009^{*} \\
(0.004)\end{array}$ & 0.049 & $\begin{array}{l}-0.008 \\
(0.035)\end{array}$ & $\begin{array}{l}0.015^{*} \\
(0.004)\end{array}$ & 0.015 \\
\hline Oceania & $\begin{array}{c}-0.039^{*} \\
(0.001)\end{array}$ & $\begin{array}{c}-0.012^{*} \\
(0.003)\end{array}$ & 0.027 & $\begin{array}{c}-0.077^{*} \\
(0.007)\end{array}$ & $\begin{array}{c}-0.017^{*} \\
(0.004)\end{array}$ & 0.061 \\
\hline Others & $\begin{array}{c}-0.041^{*} \\
(0.001)\end{array}$ & $\begin{array}{l}0.010^{*} \\
(0.005)\end{array}$ & 0.051 & $\begin{array}{c}0.012 \\
(0.014)\end{array}$ & $\begin{array}{l}0.019^{*} \\
(0.004)\end{array}$ & 0.019 \\
\hline sex & $\begin{array}{l}0.003^{*} \\
(0.001)\end{array}$ & $\begin{array}{c}0.004^{*} \\
(0.0003)\end{array}$ & & $\begin{array}{l}-0.009 \\
(0.005)\end{array}$ & $\begin{array}{c}-0.004^{*} \\
(0.001)\end{array}$ & \\
\hline no children & $\begin{array}{l}0.030^{*} \\
(0.001)\end{array}$ & $\begin{array}{c}0.018^{*} \\
(0.0004)\end{array}$ & & $\begin{array}{l}0.034^{*} \\
(0.003)\end{array}$ & $\begin{array}{l}0.017^{*} \\
(0.001)\end{array}$ & \\
\hline Years in USA & no & no & & yes & yes & \\
\hline State Dum & yes & yes & & yes & yes & \\
\hline Year Dum & no & yes & & no & yes & \\
\hline Employment & yes & yes & & yes & yes & \\
\hline Immigrant cohort & yes & yes & & no & no & \\
\hline Married Dum & yes & yes & & yes & yes & \\
\hline Health Dum & no & no & & no & no & \\
\hline Educ Dum & yes & yes & & yes & yes & \\
\hline Wages & yes & yes & & yes & yes & \\
\hline Family size & yes & yes & & yes & yes & \\
\hline age & yes & yes & & yes & yes & \\
\hline
\end{tabular}

Note: estimates are marginal impacts from probit estimation

C.A.C- Central America and the Caribbeans

* $5 \%$ significance. 
Table 7: Effect of the reform on welfare usage across groups for pre 1996 immigration cohorts?

\begin{tabular}{|c|c|c|c|c|c|c|}
\hline \multirow{2}{*}{$\begin{array}{c}\text { Variable: } \\
\text { Independent }\end{array}$} & \multicolumn{2}{|c|}{$\overline{A L L}$} & \multirow{2}{*}{$\begin{array}{c}\text { Difference } \\
(3)\end{array}$} & \multicolumn{2}{|c|}{ Only Immigrants } & \multirow{2}{*}{$\begin{array}{c}\text { Difference } \\
\\
(6)\end{array}$} \\
\hline & $\begin{array}{c}\text { anywelfare } \\
\text { (1) }\end{array}$ & $\begin{array}{c}\text { anywelfare } \\
(2)\end{array}$ & & $\begin{array}{c}\text { anywelfare } \\
\text { (excludes U.S. born) } \\
(4)\end{array}$ & $\begin{array}{c}\text { anywelfare } \\
\text { (excludes U.S. born) } \\
(5)\end{array}$ & \\
\hline & before reform & postreform & change & before reform & postreform & change \\
\hline U.S. protectorates & $\begin{array}{c}-0.068^{*} \\
(0.001)\end{array}$ & $\begin{array}{l}0.133^{*} \\
(0.024)\end{array}$ & 0.201 & $\begin{array}{l}0.239^{*} \\
(0.024)\end{array}$ & $\begin{array}{l}0.152^{*} \\
(0.007)\end{array}$ & -0.087 \\
\hline C.A.C & $\begin{array}{c}-0.104^{*} \\
(0.003)\end{array}$ & $\begin{array}{c}0.031^{*} \\
(0.0115)\end{array}$ & 0.414 & $\begin{array}{c}0.085^{*} \\
(0.012)\end{array}$ & $\begin{array}{c}0.04^{*} \\
(0.002)\end{array}$ & -0.045 \\
\hline South America & $\begin{array}{l}-0.068^{*} \\
(0.001)\end{array}$ & $\begin{array}{l}-0.001 \\
(0.011)\end{array}$ & 0.068 & $\begin{array}{l}-0.004 \\
(0.016)\end{array}$ & $\begin{array}{l}0.007^{*} \\
(0.003)\end{array}$ & 0.007 \\
\hline Europe & $\begin{array}{c}-0.081^{*} \\
(0.002)\end{array}$ & $\begin{array}{c}-0.008 \\
(0.010)\end{array}$ & 0.08 & & & \\
\hline Oceania & $\begin{array}{c}-0.064^{*} \\
(0.001)\end{array}$ & $(0.008)$ & 0.064 & $\begin{array}{c}-0.090^{*} \\
(0.019)\end{array}$ & $\begin{array}{l}0.009^{*} \\
(0.012)\end{array}$ & 0.099 \\
\hline Others & $\begin{array}{c}-0.070^{*} \\
(0.001)\end{array}$ & $\begin{array}{c}0.016^{*} \\
(0.006)\end{array}$ & 0.089 & $\begin{array}{c}0.034^{*} \\
(0.018)\end{array}$ & $\begin{array}{l}0.028^{*} \\
(0.006)\end{array}$ & -0.06 \\
\hline
\end{tabular}

Note: estimates are marginal impacts from probit estimation

C.A.C- Central America and the Caribbeans

* $5 \%$ significance. Note: Estimates that are not significant are treated as 0 in calculating the difference between

columns (1) and (2) and between (4) and (5) highlighted in column (3) and (6). controls identical to above regressions 
Table 8: Does immigration status matter for welfare usage?

\begin{tabular}{|c|c|c|c|c|c|c|}
\hline \multirow[t]{3}{*}{ Variable: } & \multicolumn{2}{|c|}{ Any Welfare } & \multicolumn{4}{|c|}{ Any Welfare exc U.S. born } \\
\hline & Naturalized & Noncitizen & Difference & Naturalized & Noncitizen & Difference \\
\hline & (1) & $(2)$ & $(3)$ & (4) & $(5)$ & (6) \\
\hline Other North America & $\begin{array}{l}-0.005^{*} \\
(0.006)\end{array}$ & $\begin{array}{l}-0.002 \\
(0.005)\end{array}$ & 0.005 & $\begin{array}{l}-0.004 \\
(0.004)\end{array}$ & $\begin{array}{l}-0.025^{*} \\
(0.005)\end{array}$ & -0.025 \\
\hline C.A.C & $\begin{array}{c}0.012 \\
(0.007)\end{array}$ & $\begin{array}{l}0.008^{*} \\
(0.004)\end{array}$ & 0.008 & $\begin{array}{l}0.038^{*} \\
(0.003)\end{array}$ & $\begin{array}{c}0.022^{*} \\
(0.003)\end{array}$ & $-0.016^{*}$ \\
\hline South America & $\begin{array}{c}0.001 \\
(0.006)\end{array}$ & $\begin{array}{l}-0.002 \\
(0.004)\end{array}$ & 0.00 & $\begin{array}{l}0.012^{*} \\
(0.003)\end{array}$ & $\begin{array}{c}-0.012^{*} \\
(0.004)\end{array}$ & $-0.024^{*}$ \\
\hline Europe & $\begin{array}{l}-0.003 \\
(0.005)\end{array}$ & $\begin{array}{c}0.010^{*} \\
(0.005)\end{array}$ & 0.010 & & & \\
\hline Asia & $\begin{array}{c}0.013 \\
(0.007)\end{array}$ & $\begin{array}{l}0.022^{*} \\
(0.006)\end{array}$ & $0.022^{*}$ & $\begin{array}{l}0.022^{*} \\
(0.003)\end{array}$ & $\begin{array}{l}0.016^{*} \\
(0.004)\end{array}$ & -0.006 \\
\hline Africa & $\begin{array}{c}0.004 \\
(0.007)\end{array}$ & $\begin{array}{c}0.033^{*} \\
(0.008)\end{array}$ & $0.033^{*}$ & $\begin{array}{c}0.023^{*} \\
(0.006)\end{array}$ & $\begin{array}{c}0.046^{*} \\
(0.008)\end{array}$ & $0.023^{*}$ \\
\hline Oceania & $\begin{array}{c}-0.008 \\
(0.008)\end{array}$ & $\begin{array}{l}0.019^{*} \\
(0.01)\end{array}$ & $0.017^{*}$ & $\begin{array}{c}0.006 \\
(0.012)\end{array}$ & $\begin{array}{c}0.019 \\
(0.013)\end{array}$ & 0.00 \\
\hline Others & $\begin{array}{l}-0.001 \\
(0.007)\end{array}$ & $\begin{array}{c}0.031^{*} \\
(0.008)\end{array}$ & $0.031^{*}$ & $\begin{array}{c}0.015^{*} \\
(0.006)\end{array}$ & $\begin{array}{c}0.048^{*} \\
(0.008)\end{array}$ & $0.023^{*}$ \\
\hline Sex & $\begin{array}{c}0.007^{*} \\
(0.0003)\end{array}$ & $\begin{array}{c}0.007^{*} \\
(0.0004)\end{array}$ & 0.000 & $\begin{array}{c}-0.003^{*} \\
(0.001)\end{array}$ & $\begin{array}{c}-0.004^{*} \\
(0.002)\end{array}$ & -0.001 \\
\hline family size & $\begin{array}{l}-0.005^{*} \\
(0.0002)\end{array}$ & $\begin{array}{l}-0.005^{*} \\
(0.0001)\end{array}$ & 0.001 & $\begin{array}{l}-0.005^{*} \\
(0.0005)\end{array}$ & $\begin{array}{l}-0.001^{*} \\
(0.0005)\end{array}$ & 0.004 \\
\hline children & $\begin{array}{c}0.026^{*} \\
(0.0004)\end{array}$ & $\begin{array}{c}0.027^{*} \\
(0.0003)\end{array}$ & 0.001 & $\begin{array}{l}0.020^{*} \\
(0.001)\end{array}$ & $\begin{array}{l}0.031^{*} \\
(0.001)\end{array}$ & 0.011 \\
\hline definc & $\begin{array}{l}0.000^{*} \\
(0.00)\end{array}$ & $\begin{array}{l}0.000^{*} \\
(0.000)\end{array}$ & 0.000 & $\begin{array}{l}0.000^{*} \\
(0.00)\end{array}$ & $\begin{array}{l}0.000^{*} \\
(0.000)\end{array}$ & 0.000 \\
\hline Years in the USA & no & no & & yes & yes & \\
\hline Year Dum & no & no & & no & no & \\
\hline State Dum & yes & yes & & yes & yes & \\
\hline Year Dum & no & yes & & no & yes & \\
\hline Employment & yes & yes & & yes & yes & \\
\hline Immigrant cohort & yse & yes & & no & no & \\
\hline Married Dum & yse & yes & & yes & yes & \\
\hline Health Dum & no & no & & no & no & \\
\hline Educ & yes & yes & & yes & yes & \\
\hline Age & yes & yes & & yes & yes & \\
\hline
\end{tabular}

Note: estimates are marginal impacts from probit estimation

C.A.C- Central America and the Caribbeans

* $5 \%$ significance.

Calculating the difference: note that estimates that are not significant are treated as 0 in finding the difference. ${ }^{*}$ on the difference column means difference is statistically significant. 
Table 9: Does immigration status matter for welfare usage?

\begin{tabular}{|c|c|c|c|c|c|c|}
\hline \multirow[t]{3}{*}{ Variable: } & \multicolumn{2}{|c|}{ Standard Welfare } & \multicolumn{4}{|c|}{ Standard Welfare exc U.S. born } \\
\hline & Naturalized & Noncitizen & Difference & Naturalized & Noncitizen & Difference \\
\hline & (1) & $(2)$ & $(3)$ & (4) & $(5)$ & (6) \\
\hline Other North America & $\begin{array}{c}-0.008^{*} \\
(0.003)\end{array}$ & $\begin{array}{l}-0.009^{*} \\
(0.002)\end{array}$ & -0.001 & $\begin{array}{l}-0.010^{*} \\
(0.002)\end{array}$ & $\begin{array}{l}-0.031^{*} \\
(0.004)\end{array}$ & -0.021 \\
\hline C.A.C & $\begin{array}{c}0.007 \\
(0.005)\end{array}$ & $\begin{array}{c}0.004 \\
(0.003)\end{array}$ & 0.00 & $\begin{array}{l}0.018 * \\
(0.002)\end{array}$ & $\begin{array}{c}0.006^{*} \\
(0.002)\end{array}$ & $-0.012^{*}$ \\
\hline South America & $\begin{array}{c}0.001 \\
(0.004)\end{array}$ & $\begin{array}{l}-0.003 \\
(0.002)\end{array}$ & 0.00 & $\begin{array}{c}0.003 \\
(0.002)\end{array}$ & $\begin{array}{c}-0.019^{*} \\
(0.002)\end{array}$ & $-0.019^{*}$ \\
\hline Europe & $\begin{array}{c}0.001 \\
(0.006)\end{array}$ & $\begin{array}{l}0.012^{*} \\
(0.004)\end{array}$ & $0.011^{*}$ & & & \\
\hline Asia & $\begin{array}{c}0.011^{*} \\
(0.006)\end{array}$ & $\begin{array}{c}0.013^{*} \\
(0.004)\end{array}$ & 0.002 & $\begin{array}{l}0.012^{*} \\
(0.002)\end{array}$ & $\begin{array}{l}0.001^{*} \\
(0.002)\end{array}$ & $-0.011^{*}$ \\
\hline Africa & $\begin{array}{c}0.001 \\
(0.005)\end{array}$ & $\begin{array}{l}0.013^{*} \\
(0.005)\end{array}$ & $0.013^{*}$ & $\begin{array}{l}0.009^{*} \\
(0.004)\end{array}$ & $\begin{array}{c}0.01^{*} \\
(0.005)\end{array}$ & 0.001 \\
\hline Oceania & $\begin{array}{c}-0.011^{*} \\
(0.004)\end{array}$ & $\begin{array}{l}-0.008 \\
(0.004)\end{array}$ & 0.011 & $\begin{array}{l}-0.008 \\
(0.005)\end{array}$ & $\begin{array}{c}-0.023^{*} \\
(0.006)\end{array}$ & $-0.023^{*}$ \\
\hline Others & $\begin{array}{l}-0.008 \\
(0.003)\end{array}$ & $\begin{array}{l}0.018^{*} \\
(0.005)\end{array}$ & $0.018^{*}$ & $\begin{array}{c}0.005 \\
(0.004)\end{array}$ & $\begin{array}{l}0.021^{*} \\
(0.006)\end{array}$ & $0.021^{*}$ \\
\hline Sex & $\begin{array}{c}0.004^{*} \\
(0.0003)\end{array}$ & $\begin{array}{c}0.004^{*} \\
(0.0003)\end{array}$ & 0.000 & $\begin{array}{c}-0.002^{*} \\
(0.001)\end{array}$ & $\begin{array}{c}-0.004^{*} \\
(0.001)\end{array}$ & -0.002 \\
\hline famsize & $\begin{array}{c}-0.002^{*} \\
(0.000)\end{array}$ & $\begin{array}{c}-0.001^{*} \\
(0.000)\end{array}$ & 0.000 & $\begin{array}{c}-0.001^{*} \\
(0.000)\end{array}$ & $\begin{array}{l}0.002^{*} \\
(0.000)\end{array}$ & 0.003 \\
\hline No child & $\begin{array}{l}0.016^{*} \\
(0.000)\end{array}$ & $\begin{array}{c}0.017^{*} \\
(0.000)\end{array}$ & 0.001 & $\begin{array}{l}0.011^{*} \\
(0.001)\end{array}$ & $\begin{array}{l}0.023^{*} \\
(0.001)\end{array}$ & 0.011 \\
\hline def inc & $\begin{array}{c}0.000^{*} \\
(0.00)\end{array}$ & $\begin{array}{c}0.000^{*} \\
(0.00)\end{array}$ & 0.000 & $\begin{array}{l}0.000^{*} \\
(0.000)\end{array}$ & $\begin{array}{c}0.00 *^{*} \\
(0.00)\end{array}$ & 0.000 \\
\hline Year in the USA & no & no & & yes & yes & \\
\hline Year Dum & no & no & & no & no & \\
\hline State Dum & yes & yes & & yes & yes & \\
\hline Employment & yes & yes & & yes & yes & \\
\hline Immigrant cohort & yes & yes & & yes & yes & \\
\hline Married Dum & yes & yes & & yes & yes & \\
\hline Health Dum & no & no & & no & no & \\
\hline Educ & yes & yes & & yes & yes & \\
\hline Age & yes & yes & & yes & yes & \\
\hline
\end{tabular}

Note: estimates are marginal impacts from probit estimation

C.A.C- Central America and the Caribbeans * $5 \%$ significance.

Calculating the difference: note that estimates that are not significant are treated as 0 in finding the difference.

* on the difference column means difference is statistically significant. 